\title{
EFFICIENCY AND EQUITY OF EUROPEAN EDUCATION AND TRAINING POLICIES
}

\author{
LUDGER WOESSMANN
}

CESIFO WORKING PAPER NO. 1779

CATEGORY 1: PUBlic FinANCE

August 2006

An electronic version of the paper may be downloaded

- from the SSRN website:

- from the RePEc website:

- from the CESifo website:

www.SSRN.com

Www.RePEc.org

www.CESifo-group.de 


\title{
EFFICIENCY AND EQUITY OF EUROPEAN EDUCATION AND TRAINING POLICIES
}

\begin{abstract}
This paper reviews empirical evidence, especially from Europe, on how education and training policies can be designed to advance both efficiency and equity. Returns to educational investments tend to decrease over the life cycle. Moreover, they seem to be highest for children from disadvantaged families at early stages and for the well-off at late stages of the life cycle. This creates complementarities between efficiency and equity at early stages and trade-offs at late stages. The paper goes on to discuss specific policies for efficiency and equity at each educational stage, ranging from early childhood education and schools over vocational and higher education to training and lifelong learning. The available evidence suggests that both efficiency and equity can be enhanced by output-oriented reforms properly designed to each stage, where the state generally sets a regulatory framework that ensures accountability and funding and uses the forces of choice and competition to deliver best results. Designed this way, education and training systems can advance efficiency and equity at the same time.
\end{abstract}

JEL Code: I28, H52, D6, J24.

Keywords: education, training, Europe, efficiency, equity, life cycle, trade-off.

Ludger Woessmann
Ifo Institute for Economic Research
at the University of Munich
Poschingerstr. 5
81679 Munich
Germany
woessmann@ifo.de

July 25, 2006

This paper is an adapted version of the Analytical Report for the European Commission that will accompany the Communication and Staff Working Paper of the European Commission on "Efficiency and Equity in European Education and Training Systems". I would like to thank David-Pascal Dion and Gabriela Schütz for extensive suggestions and discussions, as well as my fellow members of the European Expert Network on Economics of Education (EENEE, see www.education-economics.org), in particular Giorgio Brunello, Antonio Ciccone, Torberg Falch, Steve Machin, Daniel Munich, George Psacharopoulos and the external advisors Rick Hanushek and Stefan Wolter, and participants at the Munich workshop of the European Commission on the Report and SWP, in particular Daniele Checchi, Ramon Flecha, Ides Nicaise and Greg Wurzburg, for their useful discussions and extensive comments. 


\section{Introduction}

Any society aims for economic prosperity coupled with equality of opportunity. Thus, it does not surprise that European Union heads of state could agree on the so-called "Lisbon strategy" with its goal to become "the most competitive and dynamic knowledge-based economy in the world, capable of sustainable economic growth with more and better jobs and greater social cohesion". At the same time, it has been realised that education and training systems that create efficient and equitable outcomes are key for economic prosperity and social cohesion. This has been stressed by leading European economic advisors (e.g., Sapir et al. 2003; Calmfors et al. 2006), and the European Union gives central place to education and training in its agenda for jobs and growth (e.g., European Commission 2006). E.g., the European Council (2006, p. 6) concludes that "education and training are critical factors to develop the EU's long-term potential for competitiveness as well as for social cohesion." But how can an efficient and equitable education and training system be achieved in practice? This paper reviews the empirical evidence from Europe and elsewhere for conclusions on how education and training policies can be designed to advance both efficiency and equity.

The strong upsurge of applied research in the economics of education over the past decade has produced ample evidence that the monetary and non-monetary prosperity of individuals and nations indeed hinges on education and training. Education produces substantial returns to the individual in terms of earnings (cf. the surveys by Card 1999 and Harmon et al. 2003) and employability (e.g., OECD 2000, 2005a), significant effects on economic growth (e.g., Hanushek and Kimko 2000; Krueger and Lindahl 2001; de la Fuente and Doménech 2006) and noteworthy non-monetary benefits for the individual and for society as a whole, among others in terms of superior health and civic participation and reduced crime (cf. Milligan et al. 2004; Lochner and Moretti 2004; and the surveys by Wolfe and Haveman 2000, McMahon 2004 and Grossman 2006). Given the effects of education on individual well-being, the distribution of education is also crucial for societal inequality (cf. Nickell 2004).

So efficient education and training systems can create economic growth, and equitable systems can create social cohesion. Thus, for some European politicians education and training are high on the policy agenda because they can boost efficiency, for others because they can boost equity. But what is the relationship between efficiency and equity? Many governments tend to think that there is a trade-off that forces them to choose between efficiency and equity in their prioritising. But achieving more equity in the design of 
education systems may help to evade the need for intense redistributive policies at later ages that seem to hurt the creation of growth and jobs in Europe.

In reality, the relationship between efficiency and equity in education and training systems may take different forms. In some cases, efficiency and equity may be independent from one another. In other cases, there may be trade-offs in the extent to which the two goals can be achieved. And in still other cases, there may be complementarities in the achievement of the two goals. Thus, certain policies may bring education and training systems closer to efficiency, without having any impact on equity. Other policies may be highly equitable without affecting efficiency. Other policies may advance both efficiency and equity in a complementary way. And still other policies may show a trade-off by advancing either efficiency at the detriment of equity or equity at the detriment of efficiency.

It will be a key focus of this paper to highlight the presence or absence of trade-offs and complementarities in the design and functioning of education and training systems. The reviewed evidence shows that efficient policies need not be inequitable, and equitable policies need not be inefficient. Countries do not necessarily have to choose between efficiency and equity. There are ways to evade trade-offs between efficiency and equity, whereas current attempts to reach one or the other sometimes turn out to be both inefficient and inequitable.

While a universally accepted definition of equity is elusive, it seems that most people could agree to some variant close to the concept of equality of opportunity proposed by Roemer (1998; cf. Betts and Roemer 2006), which is adopted in this paper. The central idea of this concept is that inequality should be tolerated only if it is due to persons' differences in effort, but not if it is due to circumstances which are beyond a person's control. Thus, equity would demand that a person's expected educational outcome should be a function only of her effort, but not of her circumstances, such as race, gender or family background. The concept of efficiency is much more straightforward, representing a situation where a maximum educational outcome is obtained with given input or a given outcome with minimum input.

Relative to the well-established and extensive literature on the economic and social impacts of education and training, many parts of the literature on efficiency and equity in education and training are not as well developed. Ultimately, profound country-specific empirical assessments would be required to evaluate the specific efficiency and equity consequences of different policies. Still, the available literature has produced consistent evidence to warrant a general unifying perspective and many specific features for a Europewide assessment. At the same time, it should be borne in mind that uncertainties remain for some parts of the assessment, which will be mentioned where necessary. 
The analysis proceeds in two main parts. Section 2 presents a unifying framework in which investments in education and training at different stages over the life cycle are compared to each other and to alternative uses of invested resources outside the education and training system - both in the pursuit of efficiency (getting the highest returns on the resources) and equity (helping the disadvantaged). The section addresses the question where policy should spend its money - on education and training or on other investments, and if on education and training, at which stage of people's life cycle.

Section 3 goes into the details of how to design each stage of the education and training system so that the input given at each stage is used in the most efficient and equitable way. The sub-sections discuss specific policies that may change the extent to which efficiency and equity are achieved at each educational stage. The section addresses the question how policy can get the most out of a Euro spent at a specific stage of education and training, in terms of efficiency and equity. Section 4 closes with some concluding remarks.

\section{A Unifying Framework: Efficiency and Equity over the Life Cycle}

Building on the traditional theory of human capital (cf., e.g., Becker 1964), James Heckman and co-authors have developed a unifying perspective over recent years that allows to assess education and training policies over the life cycle of a person (cf., among others, Heckman 2000; Carneiro and Heckman 2003; Cunha et al. 2006). Their economic model of the technology of skill formation makes it possible to interpret the evidence on life cycle education and training in a combined framework.

\subsection{Dynamic Synergies in Skill Formation and the Life Cycle of Human Capital Policies}

The key insight of their perspective is that the formation of skills is a life cycle process that exhibits both recursive productivity and complementarity. Recursive productivity means that the education learned at one stage is an input into the learning process of the next stage. Complementarity means that the productivity with which investments at one stage of education are transformed into valuable skills is positively affected by the level of skills that a person has already obtained in the previous stages. Together, these features of recursive productivity and complementarity generate a skill multiplier whereby an investment in education at one stage raises not only directly the skills attained at that stage, but also indirectly the productivity with which educational investments at the next stage will be transformed into even further skills. These multiplier effects explain why education is a dynamic synergistic process in which early learning begets later learning. 
In their vast overviews of the empirical literature, mostly from the United States, Heckman and co-authors show that education is indeed a life cycle process that exhibits such dynamic synergies. They also stress that there are multiple important skills, both cognitive and noncognitive, and that for some of these skills (most notably on the cognitive side), there are sensitive or even critical periods in a person's life cycle where investments are particularly effective or even crucial. All this means that there are high returns to early investments, and that inadequate early investments are difficult and costly to remedy later on.

This result has profound consequences for the efficiency and equity of different policies that aim at fostering human capital. It creates a life cycle of human capital policies, where measures at early stages are particularly crucial and deficiencies that may have developed are hardly amenable at late stages. Returns to educational investments are highest in early childhood because of their effects on facilitating later learning. In addition, returns to early interventions are particularly high for children from disadvantaged backgrounds whose homes do not provide them with the foundation of skills necessary to prosper at later educational stages. Such interventions do not only build skills, but also lay the foundation that makes later learning more productive due to the complementarities in learning over the life cycle.

By contrast, in late adolescence and adulthood, returns to educational interventions are relatively low, because they do no longer create substantive synergies since even later learning is limited (and since people are beyond sensitive or critical periods to acquire certain skills). Additional reasons for the lower returns at later stages of the life cycle include that older people have a shorter time horizon during which to reap the beneficial effects of education. Skills acquired by training and lifelong learning activities may also lend themselves less easily to certification. What is more, the returns to investments at a late stage in the educational life cycle are particularly low for people who are lacking in terms of prior skills, because this lack makes their technology of forming additional skills a particularly unproductive one. This does not mean that there would be no capacity of learning during adulthood, but only that curative efforts at this late stage are particularly costly.

The stylized curves of Figure 1 depict this basic pattern of the life cycle of policies in education and training in terms of efficiency and equity graphically. The figure adapts a plot from Cunha et al. (2006) so that it depicts equity aspects in addition to efficiency aspects (see Cunha et al. 2006 for a closer discussion of the literature, model and assumptions underlying the basic version of this graph). When setting investments to be equal across the life cycle, the rate of return to a Euro invested in human capital declines with the age of a person of any background. Given the distribution of current spending across educational stages in Europe 
(cf. OECD 2005a) and given the evidence on the effectiveness of education policies at different stages presented below, the basic pattern of declining returns will also hold at current spending patterns (although it could obviously change with considerably modified policies).

\section{Figure 1: Stylized returns to a Euro spent at different stages of education and training}

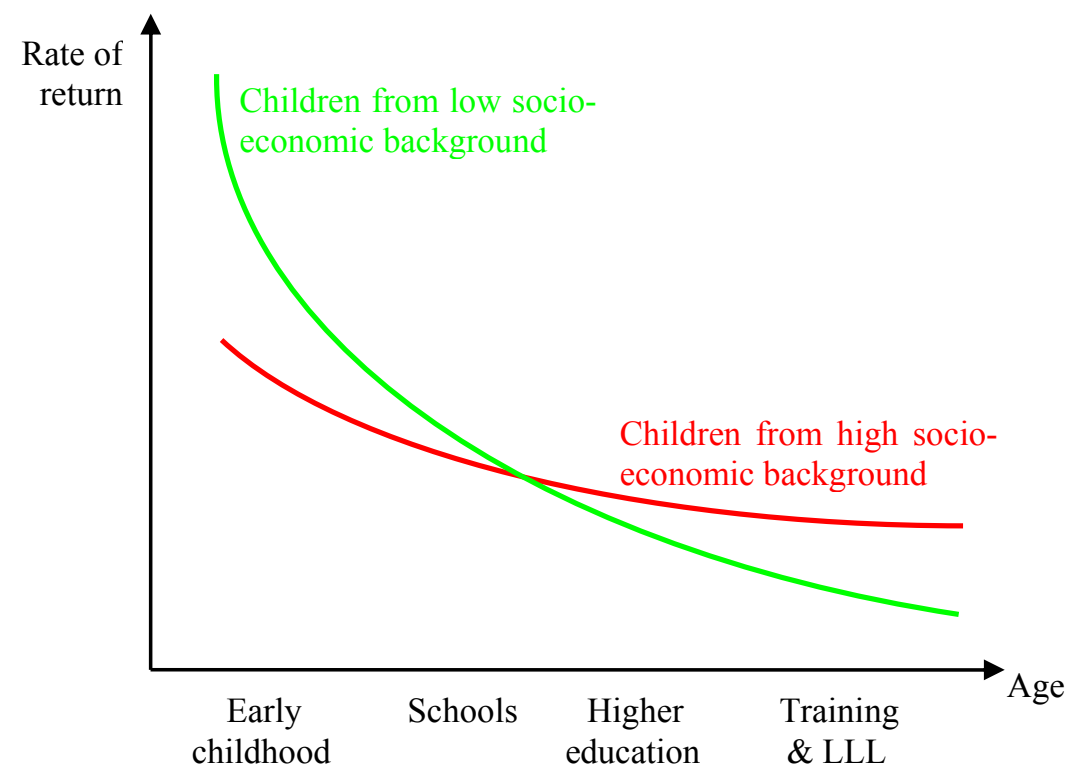

Source: Author's depiction in adaptation of Cunha et al. (2006).

Furthermore, the two graphs depict that in the lack of public intervention, rates of return decline more rapidly for children from low than from high socio-economic background. At young ages, they tend to be higher for children from disadvantaged families, but at older ages, they tend to be higher for children from well-off families. Thus, given the obvious difference of private educational spending across socio-economic backgrounds, the pattern of declining returns will hold even stronger for public spending than for total spending. It appears that the basic pattern of declining returns and differences by socio-economic background holds for private and social returns to education alike (although some evidence gathered in Psacharopoulos and Patrinos 2004 suggests that the private return may be rather flat between secondary and tertiary education, while the social return shows the declining pattern). Both features may be even more pronounced for social returns than for private returns, given the evidence on externalities in terms of reduced crime and increased civic participation (e.g., Lochner and Moretti 2004; Milligan et al. 2004).

Of course, this pattern is a rough description of average effects. There is a lot of heterogeneity within each of the two groups, and some students from low socio-economic 
backgrounds will be doing particularly well in higher education. Also, the graphs depict a situation where no additional policy intervention happens at an early age. As already argued, early interventions could raise the returns of later investments also for children from low socio-economic background. Note also that the assessment stresses a relative evaluation over the life cycle. On average, there are probably positive returns to be had at later stages of the life cycle, as well - only that they are lower than the returns to be had at early stages.

While most evidence seems to suggest that effects of early interventions can be very persistent through time, in particular for children from disadvantaged backgrounds (cf. Section 3.1 below), this is not to say that intervening in the early years alone will suffice to make the effects persist, as additional interventions at later ages might be needed to evade decay of effects. Finally, as will be discussed below, the depicted returns at the school level in particular are not necessarily to be understood in terms of spending more money within current institutional systems, but rather in terms of the returns that an improvement of the skills learned at school would bring. Because the costs of skill-enhancing institutional reforms in school systems can be very low, the rates of return for such policies, as depicted in the figure, can be relatively high (see Section 3.2 below for details).

\subsection{Complementarities and Trade-offs between Efficiency and Equity}

As a consequence of the differing rates of return over the life cycle depicted in the figure, there is a trade-off between equity and efficiency for investments in late adolescent and adult years. The most efficient policy would be to invest in students who have already acquired a lot of skills because these give them higher learning productivity, while the most equitable policy would of course target investments at those students who have obtained the fewest skills up to then. While it may or may not be technically possible to remedy the lack of early investment, such a policy may often not be cost effective. In order to reach the equity goal of raising low-skilled adults to a certain income level it may be more efficient to give them a bond that earns an interest (based on investments in physical capital or in additional human capital of high-skilled persons) which would be higher than the return on an investment in their own education or training. Thus, in terms of an external assessment, there may be better alternative uses of invested resources outside the education and training system which would be more effective in raising the income of low-skilled adults. However, to the extent that the well-being of low-skilled adults is understood not only in terms of income but also in terms of social participation, the relative preference may shift more in favour of education and training policies (see Section 3.5 below for further discussion). 
By contrast, there is no trade-off, but even a complementarity between equity and efficiency for investments in early childhood. The most efficient policy at an early stage is exactly the most equitable policy of investing in children who do not get taught necessary basic skills at home. Such investments yield particularly large returns because of their additional indirect effect of increasing the productivity of later skill acquisition of these children due to the dynamic complementarities in the technology of skill formation. It has to be stressed that this perspective requires a particularly long time horizon, which may run against the political self-interest of many policymakers, because the positive returns to early childhood investments may not be fully visible until 20 or 30 years later. But such a long-term perspective allows an assessment that shows the preferable investment strategies from a societal point of view.

While Heckman and co-authors build their view mainly on evidence from the United States, the available European evidence, which unfortunately is far less developed, suggests that the life cycle of human capital policies holds as much in Europe as in the United States. As will be discussed in detail in the next section, there is considerable European evidence that education and training policies that target low-skilled adults have often been ineffective, while the little European evidence that exists suggests that early investments have important long-lasting effects. Still, it should be borne in mind that our empirical knowledge on the relative effectiveness of interventions at different stages of the life cycle is limited in Europe, and less than perfect also in the United States (cf. Machin and Vignoles 2005).

In overall terms, the life cycle perspective on education and training policies suggests that the returns to public policies are highest at early ages and diminish over the life cycle. This implies that efficient policies would target resources particularly at the very young. In addition, at early ages the returns are highest when targeting children from disadvantaged families, so that the efficient policy is also equitable when enacted in early childhood. Only when public policies set in too late will the efficient allocation be inequitable.

\section{Policies for Efficiency and Equity at Each Educational Stage}

The previous section determined the external efficiency and equity of policies in education and training over the life cycle. The subsequent sections address the question of internal efficiency and equity of specific policies and instruments within the different stages of education and training. 


\subsection{Early Childhood Education}

\section{Efficiency:}

Evidence from the United States suggests that early childhood education can be highly efficient, especially when targeted at disadvantaged children (cf. the surveys in Barnett 1992, 1995; Currie 2001; Carneiro and Heckman 2003; Blau and Currie 2006; Cunha et al. 2006). In particular very intensive interventions such as the Perry Preschool Experiment, the Abecedarian Project and the Chicago Child-Parent Center Program, which have been scientifically evaluated using either an experimental setup or statistical matching techniques, show that participating children from disadvantaged backgrounds achieve superior educational outcomes in terms of test scores, grade retention and high school graduation, as well as reduced crime and delinquency. The studies that follow the participants into adult ages also show positive long-run effects on labour market outcomes, criminal and other behaviour. The benefits of these intervention programmes have been shown to exceed their costs by a multiple (cf. Belfield et al. 2006). Although the features that make a proper design for highquality pre-school programmes are not well researched (cf. Currie 2001), a specific feature in terms of boosting outcomes seems to be the intensity of the programmes, such as setting in at very early ages, involving parents through home visits and generally intensive setups (cf. Cunha et al. 2006).

For European countries, there does not seem to be much comparable evidence in terms of the well-founded scientific research designs that try to establish causality in the US evaluations. For the Netherlands, Leuven et al. (2004) show that lowering the school starting age, which is already as low as four years, would increase later educational performance of disadvantaged students. Feinstein et al. (1999) find more mixed effects of pre-school attendance in the United Kingdom, which they ponder might hint at a relatively low quality of provision. Still, Feinstein (2003) shows that cognitive achievement in early childhood has a clear association with the educational qualifications of UK adults in their mid-20s, which indicates that there are substantial potential effects for early childhood interventions. In line with this, Goodman and Sianesi (2005) find significant and long-lasting effects of early education on educational and labour-market outcomes in Britain. Kamerman et al. (2006) survey additional, particularly psychological studies from France, Sweden and the United Kingdom which suggest that participation in high-quality early childhood education and care programmes is positively associated with the cognitive, social and emotional development of 
children, their school readiness and school performance, with associations being especially strong for children from disadvantaged backgrounds.

In terms of international comparisons with many European countries, Fuchs and Wößmann (2004) show that kindergarten attendance and particularly pre-school reading performance are associated with higher performance at the end of primary school, even after controlling for a vast number of family-background and school effects. Schütz et al. (2005) find similar effects between the length of a country's pre-school education system and cognitive performance in middle school. The European and cross-country evidence should be taken cautiously, though, because it is based on relatively few studies and is mostly in terms of controlled descriptive associations without necessarily distilling causality.

On a less rigorous level, there is a strong feeling in many European countries that there is a lack of knowledge about the quality of early childhood education and care programmes, because they do not tend to be controlled or tested (for an example, see OECD 2004). Due to deficiencies in clarity and monitoring of goals and standards, the early childhood education systems tend to lack accountability. In some cases, such as Germany, there is also some worry about the low training level of staff and the weak link between pre-school and school system. The US evidence shows that the more intensive programmes show better results, suggesting that early childhood education is not just about day care. For Britain, Goodman and Sianesi (2005) similarly find that effects of education-based programmes are longer lasting than effects of attendance in nursery or playground programmes. In that sense, programmes such as the French école maternelle, which has a curriculum to teach children the basics of reading, writing and calculating, may be substantially more effective in fostering skills than programmes such as the German Krippe and Kindergarten, which function mainly as day care centres without strong educational mandate. Given the little and mixed evidence from Europe, it is not clear to which extent putting more money into current European early education systems without accounting for outcomes would indeed raise achievement and later labourmarket outcomes.

\section{Equity:}

As indicated before, the US evidence shows that early intervention programmes targeted at children with disadvantaged backgrounds carry particularly large positive returns. Thus, policy measures to increase equality of educational opportunity through interventions in early childhood have the potential to yield very high returns. The positive effects of earlier education in the Dutch study were likewise restricted to the students from disadvantaged 
backgrounds (Leuven et al. 2004). In their cross-country research, Schütz et al. (2005) find that more extensive systems of pre-school education - in terms of both enrolment and duration - significantly increase equality of opportunity, as measured by a lower dependence of eighth-grade students' test scores on their family background. Thus, early childhood education programmes that are particularly targeted at disadvantaged children seem to have strong potential for raising equity.

A key issue here is whether effects from early interventions persist or decay through time. For the intensive US programmes that have been followed through adulthood, substantial long-lasting effects on economic and social outcomes have been shown in particular for children from disadvantaged backgrounds. Among others, these long-run effects include impacts on school achievement, grade retention, employment, earnings, social adjustment, crime prevention, family relationships and health, and by now have been found to carry through to ages as high as forty (for details, cf. Barnett 1992, 1995; Garces and Currie 2002; Schweinhart et al. 2005; Cunha et al. 2006; Belfield et al. 2006). While Magnuson et al. (2004) report that the positive cognitive effects of US pre-kindergarten programmes fade quickly on average, and that there are negative non-cognitive effects in terms of aggression and self-control, their results also show that there are more lasting cognitive gains for disadvantaged children and for those who get low instruction in early school years. Thus, even their more mixed results suggest that the effects of early interventions are long-lasting for the disadvantaged.

In the United Kingdom, Goodman and Sianesi (2005) find significant long-lasting effects of early childhood education on obtaining qualifications, employment and earnings at age 33. Analysing students' cognitive achievement during school life, Feinstein (2004) finds that differences in educational attainment along the socio-economic dimension - which carry through to adult economic outcomes - accumulate throughout school life. This suggests that to achieve equality of opportunity, the required early childhood investments may need to be supplemented by targeted investments for the disadvantaged throughout school. But UK evidence by Currie and Thomas (2001) suggests that the increase in differences in educational performance by socio-economic background during adolescence may be largely due to differences in school quality, so that a policy of equality of treatment at the school level may suffice once early interventions have laid an equal footing. Still, the evidence on the persistence of the effects of early interventions is limited, and if the positive effects of early interventions were to decay over the education life cycle, there would of course be more scope and need for interventions also at later ages. 


\section{Complementarity or trade-off:}

Given that early childhood education programmes can be both efficient and equitable, there is obviously no efficiency-equity trade-off for early investment. Quite to the contrary, in particular when targeted at the disadvantaged, there is a strong complementarity between efficiency and equity in well-designed early childhood educational interventions, whose effects seem to be able to persist through adulthood.

\subsection{Schools}

Education policy at the school level can impact on efficiency and equity, but a key issue here is that one needs to be very careful about determining which policies are more effective in achieving these goals than others. This section discusses the evidence on the relative effectiveness of different policies to affect efficiency and equity at the school level.

\section{Efficiency:}

Ample evidence shows that the quantity and especially the quality of schooling, in terms of student performance on cognitive achievement tests, carry substantial payoffs of productivity and earnings in the labour market for the individual and society alike (cf. Bishop 1989, 1992, Neal and Johnson 1996, OECD 2000, McIntosh and Vignoles 2001, Currie and Thomas 2001 and the references in the latter for examples of individual evidence and Hanushek and Kimko 2000, Barro 2001 and Wößmann 2002 for examples of macro evidence). Earnings returns to the quality of schooling seem to have been increasing over time (Murnane et al. 1995), and there are substantial earnings returns to basic cognitive skills even among school dropouts, that is, students with the lowest quantitative school attainment (Tyler et al. 2000). Moreover, while returns to educational quantity decrease with the time that employers can observe individuals in the labour market, returns to cognitive achievement increase (Altonji and Pierret 2001). Therefore, and given that most European countries achieve virtually universal enrolment in terms of the quantity of primary and (at least lower) secondary schooling, it is particularly any policy that increases the quality of schooling in terms of students' cognitive and non-cognitive skills that may bring considerable benefits with it.

However, research shows that there is no clear, systematic relationship between student achievement and the amount of resources spent on schools (see, e.g., Hanushek 2003 for an overview; Wößmann 2005a and the references therein for accumulating evidence from Europe; Wößmann 2003 for cross-country evidence; and Gundlach et al. 2001 for evidence from several European countries over time). In most European school systems, on average 
there seems to be virtually no effect of class size or per-pupil spending on the cognitive skills acquired by students. While results for teacher education and experience and for endowment with instructional material are more mixed, the evidence overall gives little hope that substantial gains in measured test scores would emanate if European countries increased their spending without changing the current institutional structures of their school systems.

In contrast, a lot of research has accumulated over recent years showing that the efficiency of the school system, in terms of cognitive skills per Euro spent (unfortunately, not much is known on efficiency in terms of non-cognitive skills), can be substantially increased by institutional reforms that focus the incentives of all actors in the system on increasing the performance of students. Given that most of these reforms are institutional changes that do not have major impacts on the spending level in the system, the gains in cognitive skills that they can elicit are pure efficiency gains.

One of the most promising institutional structures that could lead to substantial gains in many European education systems is a combination of accountability and school autonomy. International evidence suggests that institutional features that introduce accountability by externally testing and making public the quality of what students and schools deliver, e.g. in terms of external exit examinations, create the proper incentives to improve educational performance (cf. Bishop 1997, 2006; Bishop and Wößmann 2004; Betts 1998; Jürges et al. 2005; Wößmann 2002, 2003, 2005b). Similar to the positive effects of external exit examinations, Figlio and Lucas (2004) report US evidence on positive effects of grading standards on student achievement. Another means to increase accountability are explicit school-focused accountability systems, which have been shown to increase students' learning achievement in the United States (Hanushek and Raymond 2004; Jacob 2005).

At the same time, it should be borne in mind that designing proper accountability systems that hold actors accountable for only those outcomes for which they are really responsible is not an easy task. External exit exams can introduce incentives for students if they produce signals of accomplishment that have real consequences for students. Bishop (2006) suggests that a well-designed system of external exit examinations should be curriculum-based, define achievement relative to an external standard, measure the full range and signal multiple levels of achievement, and cover the vast majority of students. By contrast, accountability systems that aim to create proper incentives for schools require a value-added approach which tests the learning gains (rather than levels) of each individual student (cf. Kane and Staiger 2002; Ladd and Walsh 2002). School-focused accountability systems can also lead to strategic responses on part of teachers and schools, for example by increasing placements of low-performing 
students in special-education programs which are outside the accountability system or by preemptively retaining students (Jacob 2005). High-stakes testing may even introduce incentives for outright teacher cheating (Jacob and Levitt 2003). Thus, in implementing accountability systems, it is crucial to provide means that keep strategic responses and fraud to a minimum.

As another institutional feature that can increase the quality and effectiveness of European educational systems, school autonomy in personnel and process decisions can be beneficial for student learning, at least in systems where external exit exams introduce accountability. In several decision-making areas such as teacher salaries, course contents and school budgets, the cross-country evidence based on different international student achievement tests suggests that local decision-making without external exams is detrimental for student performance. But the effect turns around to be positive where external exams exist (cf. Wößmann 2005b). Thus, decentralisation works - if combined with the accountability introduced by external exams.

In effect, external exams and local decision-making complement each other in increasing the efficiency of education systems. By introducing accountability, external exams mitigate the negative effects of decentralisation due to opportunistic behaviour, ensuring a positive net effect of decentralisation due to superior local knowledge. The frequently urged decentralisation of school systems can enhance performance only if external exams provide the right incentives for local decision-makers to act in a manner which promotes better performance. Therefore, an efficient education policy would combine external exams with school autonomy. That is, it would specify standards and monitor their attainment, but simultaneously leave it up to the schools how these standards should be reached.

An institutional set-up that combines accountability with parental choice are systems which give students in schools that repeatedly do badly on the accountability test a voucher to attend private schools. In Florida, the threat of becoming subject to private-school choice if failing on the test has been found to increase school performance particularly for disadvantaged students (West and Peterson 2006).

More generally, policies that introduce competition, choice and market forces into the school system have been shown to have strong potential to shift school systems to a higher level of efficiency (for some background, cf. Hanushek et al. 1994; Shleifer 1998; Nechyba 2000; and Hoxby 2003a). Sandström and Bergström (2005) provide evidence on significant positive effects of competition from privately operated schools on the performance of public schools in Sweden (cf. Björklund et al. 2004 for similar results). Bradley and Taylor (2004) and Levacić (2004) find similar positive effects of school competition on the performance of English schools, and the former show that these efficiency gains are achieved without 
significant increases in polarization. Filer and Münich (2003) show that the introduction of a voucher-type system in the Czech Republic led to the creation of private schools in areas where public schools are doing badly and that the public schools facing private competition improved their performance in obtaining university admission for their graduates.

In a cross-country analysis, Wößmann $(2003,2005$ c) shows that countries with a larger share of privately operated schools perform better on international achievement tests, after controlling for a host of other influences. At the same time, across countries, larger shares of public funding (as opposed to operation) are associated with better student outcomes. Since public funding may increase the set of choices for poor families, the positive effect of public funding may be another aspect of the skill-enhancing capacity of school choice and competition. While the extent to which this descriptive evidence depicts causal relationships remains to be seen, the international evidence is still suggestive in the sense that school systems based on public-private partnerships where the state finances schools but contracts their operation out to the private sector seem to be the most effective school systems.

Similar evidence of positive effects of school choice on student performance exists for the United States. The evidence provided by Neal $(1997,2002)$ suggests that the choice of private Catholic schools leads to higher performance of US inner-city students. Hoxby (2003b) summarizes ample evidence from recent policy experiments in the United States indicating that school choice and school competition improve the performance not only of these schools, but also of the public schools that face their competition. Peterson et al. (2003) provide evidence from several randomized field trials in the United States showing that school vouchers substantially increased the academic performance of African Americans who were enabled to attend a private school. However, there are also sceptics who argue that efficiency gains from a widespread voucher system might be small (Ladd 2002). Within the traditional public system, increased competition among US public schools has been shown to improve student performance, as well (Hoxby 2000). Charter schools, publicly financed and overseen schools that have substantial independence, constitute a new form of competition within the US public school system and have been shown to improve student performance in some states but not in others (cf. Hanushek et al. 2005 and the references therein).

Another policy with the potential to increase efficiency in the school system are financial incentives for teachers (cf. Lazear 2003a). Atkinson et al. (2004) find that the introduction of performance-related pay had a substantial positive impact on student achievement in England (see also their survey of other studies, the more rigorous of which also tend to find a positive relationship between financial teacher incentives and student outcomes). Similarly, Lavy 
(2002, 2004) has shown that monetary incentives for teachers based on their students' performance improved efficiency immensely in Israeli schools, with incentives for individual teachers being more efficient than teacher group incentives. The improvements in student performance due to performance-related pay for teachers appear to derive from changes in teaching methods, after-school teaching and increased responsiveness to students' needs.

Teacher incentives are particularly crucial because arguably, apart from the students themselves, teachers constitute the most important "input" in the education process. Teachers have been shown to differ severely in the amounts of knowledge that they convey to the same students (cf. Rivkin et al. 2005). The problem in terms of political utilisation is that teacher quality thus measured is hardly related to measurable features of teachers such as their level of education or experience. Thus, while improving teacher quality would beyond doubt increase the efficiency of schooling, there is currently little knowledge on how to best advance teacher quality. However, one component of teacher quality that is conducive to student outcomes seems to be teachers' academic proficiency (Eide et al. 2004). Eide et al. (2004) argue that the disconnection between the structure of teacher compensation and the individual teacher's performance is at the heart of the problem of the increasing difficulty of hiring and retaining high-skilled teachers. In line with this argument, Hoxby and Leigh (2004) show that pay compression due to unionization can explain a major part of the decline in teacher aptitude in the United States. Hoxby (2002) shows that different forms of school choice induce schools to hire higher-quality teachers. While many attempts at introducing performance-related reward programmes have been unsuccessful due to poor design and implementation, for example due to a lack of clarity in goals and reliability of criteria, well designed and implemented schemes that recognize and reward teacher performance stand a good chance of improving student outcomes (cf. OECD 2005b for a review).

On a more descriptive basis, OECD (2005b) provides a good review of international experiences on attracting, developing and retaining effective teachers. Important lessons include an emphasis of teacher quality over teacher quantity, a flexible and ongoing scheme of teacher education and development aligned with school needs, and school autonomy in teacher personnel management. To improve teacher quality, it is suggested to pay attention to the selection criteria for teacher education and employment, ongoing teacher evaluation throughout their career, and recognition and reward for effective teaching.

Taken together, policies that set the right incentives for students, teachers, schools, administrators and parents can contribute substantially towards increasing the efficiency of resource use in schooling. Institutional reforms that may enhance efficiency in school systems 
include external exit exam systems and other accountability systems, school autonomy in personnel and process decisions, competition and choice, and performance-related rewards.

\section{Equity:}

The degree of equality of educational opportunities that is reached by school systems varies considerably across countries. While in some countries, students' educational performance is strongly predetermined by their family background, this is much less the case in other countries (cf. Schütz et al. 2005).

However, similar to the goal of efficiency, it seems hard to achieve more equity by just increasing educational spending on students from disadvantaged backgrounds. There is very little evidence suggesting that spending targeted at disadvantaged students is any more effective than spending on average. Thus, Leuven and Oosterbeek (2006) report quasiexperimental evidence from the Netherlands showing that for a broad range of interventions targeted at disadvantaged groups, such as class-size reductions, extra resources for personnel and extra resources for computers, substantial positive effects can be ruled out. Similarly, it has proven hard to find a significant effect of the policy of education priority zones in France, which channel additional resources to disadvantaged schools (Bénabou et al. 2004). Also, much US evidence suggests that the extent to which a refocusing of additional material resources towards the disadvantaged can alter the distribution of educational outcomes is very limited at best (cf. Betts and Roemer 2006; Hanushek 2006), although there are studies that find that class-size reductions are more effective for disadvantaged students (cf. Krueger 1999).

One policy with substantial impact on the equality of opportunity achieved in a school system is the timing of the tracking of students into different kinds of schools based on their ability. It seems that early tracking, e.g. at age ten to twelve, as is common in several European school systems, is particularly harmful for children from families with low socioeconomic status and therefore hinders reaching equality of educational opportunity (for evidence, see Hanushek and Wößmann 2006; Schütz et al. 2005; Ammermüller 2005; Bauer and Riphahn 2006; Dustmann 2004). Therefore, postponing tracking to a later stage in the educational process can act as a policy to increase equality of opportunity at the school level.

A second policy that seems to affect equity at the level of compulsory schooling is the size of the pre-school education system in a country (cf. Section 3.1 above). Thus, an extensive system of early education in terms of both duration and universal enrolment can be viewed as another policy to increase equality of educational opportunity at the school level (cf. Schütz et 
al. 2005). In a similar vein, Leuven and Oosterbeek (2006) find for the Netherlands that lowering the compulsory school attendance age is the only intervention analyzed which produces significant positive effects for disadvantaged students. While equalizing effects might also be expected from whole-day schooling, the cross-country pattern does not show clear evidence for equalizing effects (Schütz et al. 2005).

Some of the above-mentioned institutional reforms that can boost efficiency may also be used to increase equity. For example, simulation studies by Nechyba (2000) show that a voucher system which gives choice to poor families can actually serve equity goals, e.g. by integrating neighbourhoods. This is even more so when the vouchers are designed to explicitly target disadvantaged families. In particular, because existing systems already have a lot of segregation, introducing choice can decrease the segregation due to mobility. Likewise, in the Florida setup which combines accountability with choice, it was especially the disadvantaged students whose educational performance gained from the threat of becoming subject to private-school choice if schools failed on an accountability test (West and Peterson 2006). Charter schools also tend to disproportionately serve disadvantaged students whose regular schools were performing badly (cf. Hoxby 2003b). Hanushek et al. (2005) show that parents seem to be capable of choosing in a well-informed way in the sense that they tend to exit charter schools of low quality, although this tendency is weaker for students from poor families. To promote equity, financial incentives for teachers can also be targeted at at-risk students to particularly boost their performance (Lavy 2002, 2004).

Improving the quality of the teaching force of disadvantaged students could certainly advance the cause of equity. Ensuring that all students have access to high quality teaching, with capable people wanting to teach also in disadvantaged schools and with a high quality of their teaching, will help in raising the equity of schooling (cf. OECD 2005b). But the problem is again that current knowledge on practical means on how to achieve this is limited. Training teachers to identify learning problems early on might help, although empirical evidence on this is missing. A fundamental problem for equity in this area is the endogeneity of the distribution of teachers, in that better teachers may tend to choose to teach in relatively welloff schools, so that schools in problematic neighbourhoods have problems in attracting highquality teachers (cf. Bonesrønning et al. 2005).

\section{Complementarity or trade-off:}

The current knowledge on the effects of schools and school policies is mostly limited to effects on cognitive skills, while there is not much research on non-cognitive and longer-term 
outcomes. Clearly, more research needs to be done here, particularly in Europe. But at the current level of knowledge, it seems fair to conclude that there appears to be no strong evidence for a substantive trade-off between efficiency and equity at the school level. Across countries, performance levels and the distribution of outcomes are largely unrelated (Schütz et al. 2005). With respect to specific policies acting at the school level, it often seems that policies that increase efficiency are neutral with respect to equity, while equity-conducive policies do not strongly affect efficiency. For example, Bradley and Taylor (2004) find that competition has positive effects on efficiency in UK secondary education, without significant polarization. Likewise, early tracking of students into different-ability schools has been found to increase inequality, while there is hardly any evidence that it would improve efficiency, at least in terms of basic cognitive skills (Hanushek and Wößmann 2006). If anything, there might even be a slight complementarity for this policy, in that later tracking reduces inequality and seems to have a slight positive impact on efficiency.

More generally, there is also evidence for complementarities of certain policies in raising both efficiency and equity, most notably for policies of early education and well-designed forms of choice and accountability. In terms of pre-school education systems, it was already discussed that extensive intervention programmes in early childhood can be both equitable and efficient. Similarly, Schütz et al. (2005) find that an extensive system of early-childhood education can improve equity in the school system, and at least the length of pre-schooling is also positively associated with average school performance across countries.

As discussed above, Wößmann (2005c) provides evidence for a strong complementarity between efficiency and equity policies in the sense that public funding of schools combines very well with private operation. In fact, public funding even seems to improve efficiency, presumably because it allows additional choice and thus competition for families who could otherwise not choose because they are credit constrained. If public money is allowed to go to privately operated schools, this is the most efficiency-conducive combination. Thus, even in terms of mere efficiency, education systems where the state does the funding and the private sector runs the schools seem to outperform all other kinds of system. At the same time, Schütz et al. (2005) find that public funding improves equity, as does private operation. Combining private operation with public funding may thus be conducive to both efficiency and equity.

Similarly, while many people fear that voucher-based choice systems in education might reduce equity at the expense of efficiency, the simulations by Nechyba (2000) suggest that it is actually more likely that voucher systems would also improve equity, particularly with a well-targeted voucher design. West and Peterson (2006) find that choice threats embedded 
within accountability systems in Florida not only boosted average performance, but in particular favoured disadvantaged students. Similar equity-enhancing effects have been found for voucher and charter school programs (Hoxby 2003b). On the other hand, Burgess et al. (2006) find a positive association between the size of the choice set of nearby schools and post-residential stratification of students across schools in England, although the effect of school choice on initial residential choices is not clear. Björklund et al. (2004) also suggest that there are signs that competition from privately operated schools increased segregation and dispersion of student performance in Sweden, although they also show that the association between family background and student performance did not change. In general, issues of implementation seem crucial when competition is introduced in schooling, and without proper safeguards, critics fear that competition may induce cream skimming, increase segregation and lead to adverse effects on disadvantaged students (e.g., Ladd 2002). A proper design of an equitable voucher system and of limits to cream skimming by schools is thus a crucial task to ensure equitable outcomes. Issues of design and implementation of school choice to improve both efficiency and equity contain measures such as the flow of information to parents and regulatory and financial frameworks and incentives, which can be devised to encourage socio-economic integration (cf. Betts and Loveless 2005).

In terms of accountability systems, Wößmann (2005b) finds that central exams are strongly positively related to higher average levels of performance, while at the same time there is some evidence that they can reduce the disadvantage of coming from an immigrant background. There is also some tentative evidence that central exams may be able to increase equity along the parental-education dimension, although evidence here is much more mixed and may be better interpreted as central exams being rather neutral with respect to equity.

All in all, equity-enhancing structures often also seem to serve to improve educational efficiency and vice versa, showing few signs of an equity-efficiency trade-off in the structure of school systems. Even more, efficiency-conducive policies can be targeted at disadvantaged students in order to boost equity goals, as has been shown, for example, in the case of targeted teacher incentives (Lavy 2002, 2004). Ultimately, if schools challenge all students to their highest potential, an efficient school system can also be equitable at the same time (cf. Arrow et al. 2000; Wößmann and Peterson 2006).

\subsection{Vocational Education}

In several European countries, vocational education plays an important role at the end of or directly after the compulsory schooling cycle (issues of continuous training later in life will be 
discussed in Section 3.5 below). The main feature of vocational education programmes is that rather than aiming at the provision of general skills that can be used in a variety of different activities, they provide an education that prepares for specific tasks. Such programmes may be either solely school-based, or - more often - they may combine vocational schooling with work experience on the job, as in apprenticeship contracts. In the latter case, vocational programmes differ from programmes of general education in that the educational decisions are not only made by students and their families, but also by firms.

The debate on vocational versus academic qualifications and their payoffs is more heated in some European countries than others. But despite its prevalence in many European countries, there is a general lack of hard empirical evidence on which to base a sound analysis of efficiency and equity issues in vocational education (cf. Leney et al. 2004). Consequently, the scientific assessment is forced to remain very limited. Furthermore, the extent, design and pattern of operation of vocational education are very different across European countries (cf. Lynch 1994) and even across sectors within countries (e.g., Franz and Soskice 1995), so that Europe-wide assessments are particularly hard to arrive at for this type of education.

\section{Efficiency:}

The economic returns to vocational education on the labour market are scientifically particularly hard to identify because lower-ability students tend to sort themselves into these types of education. While descriptive comparisons tend to find that returns to vocational education may be lower than returns to general education (Psacharopoulos 1994), and while the size of the returns may differ considerably across European countries, it seems that vocational education does carry reasonable earnings returns in countries with well-developed systems of vocational education (cf. Lauer and Steiner 2000 for an example; cf. also Bishop 1994). Countries with well-established apprenticeship systems also tend to show lower shares of students without any post-compulsory education and lower youth unemployment (cf. Ryan 1998). On the other hand, they also appear to show large unemployment among older people who previously went through the apprenticeship system, suggesting that there is an increased obsolescence of specific skills due to rapid technical change.

In general, well-developed apprenticeship systems that combine specific education in vocational schools with on-the-job training in firms tend to receive positive assessments from economists (e.g., Steedman 1993; Acemoglu 2001; Clark and Fahr 2002). It is argued that the combination of vocational education with job experience facilitates the transition from schooling to work (cf. Ryan 2001 for a review) and motivates students to perform well and 
firms to provide decent training. For example, Bonnal et al. (2002) show that apprenticeship schemes with within-firm training are better suited to facilitate the school-to-work transition in France than pure vocational schools. But apprenticeship contracts and their success in Europe differ substantially. It seems that the design of adequate schemes is important to foster satisfactory skill formation. Among others, a sufficient duration of the apprenticeship schemes may be vital (cf. Euwals and Winkelmann 2004 for evidence of positive labourmarket outcomes of longer apprenticeship duration in Germany), as might be proper certification and quality monitoring by the state (cf. Acemoglu and Pischke 1999). It has also been argued that a high level of competition among firms offering apprenticeships and among students is important to assure success (Heckman 2000). But in general, the empirical knowledge on what determines a successful system of vocational education is very limited.

For example, Germany - a country with one of the most developed apprenticeship systems - has witnessed an increasing gap between the declining demand for apprentices by firms and the supply of students wishing to enter the apprenticeship system. This lack of apprenticeship training positions could point at inefficiencies, in the sense that training apprentices is too costly for firms. Swiss evidence shows that firms' probability to train apprentices is strongly affected by the ratio between costs and benefits of training to them, in particular in terms of whether there are benefits of work to be performed productively by apprentices (Muehlemann et al. 2005; Wolter et al. 2006). However, the German gap need not be a sign of general inefficiencies, but may rather be a sign of an improper sharing of costs between apprentices, firms and the state. Because of a shift of time from productive workplace activities to education, disproportionately large increases in apprentice earnings and a shift in teaching towards more general rather than firm-specific skills (Wößmann 2004), the financial burden may have to shift away from firms towards apprentices in order for the gap to be closed.

In a less developed vocational system, the United Kingdom has faced the problem of a proliferation of vocational qualifications that weakened the signal of what students who attend a vocational programme learn (cf. Machin and Vignoles 2005). As a consequence, employers are unaware of the skills provided and thus unwilling to reward vocational credentials.

In general, these experiences suggest that it is important for an efficient vocational education system to provide qualifications well-tailored to market needs, both in terms of content and in terms of signalling these contents. Provision by the private sector combined with certification by the public sector may be one means of achieving these goals. 


\section{Equity:}

For students who do not reach the standards of academic skills necessary to succeed in general higher education courses, acquiring the more practical skills of vocational education programmes may be a viable road towards skill improvements, especially when the education is combined with training on the job. In France, the particularly disadvantaged students who tend to opt for apprenticeships gain from these apprenticeships in being more likely to find a job than students who obtained a merely school-based vocational education (Bonnal et al. 2002). On a descriptive level, there is an unconditional negative association between the share of students in vocational education and the proportion of early school leavers across European countries (Leney et al. 2004), suggesting that vocational programmes may help to reduce the incidence of school dropouts and thus target the most disadvantaged students.

On the other hand, the technological changes over recent decades have reduced the demand for relatively low-skilled workers (cf. Machin 2004), which may partly also hit vocational qualifications. It is a common experience over recent years that young adults who have left school with low grades have increasing difficulties in finding positions in vocational training. German evidence shows that lower-educated school leavers are selected into apprenticeships with less favourable employment prospects, and over time, they also find it increasingly difficult to transfer successfully from apprenticeship to work (Büchel 2002). This underlines the life cycle perspective taken above which stresses the importance of a high-quality education up to the school level.

Furthermore, the long-run payoffs to the relatively specific skills obtained in vocational education programmes may have declined due to more rapid obsolescence of specific skills caused by increasingly rapid technological change. Krueger and Kumar (2004) present a model calibration suggesting that the European focus on specialized, vocational education might have been successful during the 1960s/70s. But they show that the difference in education policy to the more concept-based, general education of the United States may be able to explain much of the lag in European growth when new technologies emerged more rapidly during the subsequent information age. Thus, the necessity of tailoring for market needs in order for vocational programmes to be effective is hard to achieve, because market needs in some areas are changing fast and often differ spatially. In particular, narrow vocational education run the problem of mismatching with market needs, a problem amplified by low skill multipliers of vocational skills. Because of the impossibility of planning vocational education given rapid technological advances, it may be more effective to enhance the level of general competence of students from low socio-economic background, and brief 
stages of vocational specialization can take place throughout the labour-market career of the individual (cf. Psacharopoulos 1991).

\section{Complementarity or trade-off:}

Given the extremely tentative character of the assessments of efficiency and equity issues in vocational education, it seems hard to come to a conclusion about the possible complementarities or trade-offs between efficiency and equity at this stage of the education system. The only conclusion that seems reasonable to make is that any initiative that manages to increase the efficiency of vocational education programmes in all likelihood would also help the cause of overall equity in the system, because in relative terms it is the students from lower socio-economic backgrounds who enter the vocational system in larger shares. But without clearer evidence on the internal and external efficiency and equity of vocational education, any assessment will have to remain far from satisfactory.

\subsection{Higher Education}

In contrast to the vocational qualifications discussed in the previous section, higher education obtained at colleges, polytechnics and universities tends to impart more academic qualifications. While the empirical evidence on issues of efficiency and equity in European higher education is meagre at best, there is a substantial literature advancing theoretical arguments, often based on practical observations, in particular related to the financing side of higher education (see the reviews by Barr 2004 and Greenaway and Haynes 2004).

\section{Efficiency:}

Higher education is generally associated with high returns on the labour market in terms of earnings and employability (cf., e.g., Card 1999; Harmon et al. 2003; OECD 2005a), suggesting that obtaining a higher education degree can be a highly efficient investment. Over the last two decades of the twentieth century, there has been a strong shift in demand towards high-skilled workers in the majority of industrialized countries (cf. the surveys in Machin 2004 and chapter 10 of Cahuc and Zylberberg 2004). Mostly driven by technological changes that are biased in favour of high-skilled tasks, employers seem to be increasingly demanding workers with graduate qualifications, which has increased their relative labour-market prospects in terms of employability and earnings. In countries close to the technological frontier, returns to higher education may even be the highest ones (cf. Vandenbussche et al. 2004). 
The amount of private spending on higher education might be inefficiently low if a lot of families were truly credit constrained in the traditional sense, that is, their children would not enter higher education because their families do not have the financial means to pay for it at the time of decision-making. However, ample evidence from the United States suggests that true credit constraints are not a binding issue in the admission to higher education in the vast majority of cases (cf. Carneiro and Heckman 2003; Cunha et al. 2006). Rather, the fact that students from disadvantaged family backgrounds have a much lower probability of entering university seems to be caused by a lack of early educational investments which deprive these students of the basic prerequisites to advance to university. If this is true in the United States, where colleges and universities charge substantial private fees, then it seems that it is even more relevant in Europe, where higher education is mostly publicly funded. For example, a major determinant of degree performance in UK universities is students' performance on Alevel scores at the school level (Smith and Naylor 2001), and academic preparedness is the major determinant of dropout of medical students in UK universities (Arulampalam 2004b). Thus, financial interventions at the late stage of higher education are unlikely to facilitate efficient investments - the intervention should have happened much earlier in the educational life cycle (see Section 2.1 above).

In terms of technical efficiency, in many European countries there is a growing feeling that current systems of higher education are not organized in an efficient way. While empirical evidence on this is hard to come by, many commentators, such as the German Council of Economic Experts, allege that current systems of higher education, which are traditionally run under state control and employee management in many European countries, exhibit a high degree of inefficiency. Psacharopoulos (2005) provides descriptive evidence supportive of this view, and Lowry (2004) presents US evidence showing that public universities faced with little competition and universities that rely heavily on government subsidies perform worse in terms of graduation rates in undergraduate education. As a consequence, commentators suggest that efficiency in European higher education could be raised by introducing competition, which would provide market discipline to the behaviour of providers. In Germany, for example, the Council of Economic Experts proposed market-based reforms that would organize higher education in a competitive framework, allow colleges and universities freedom from bureaucratic interventions, and give the actors incentives for superior performance and quality, among others through performance-related pay (Sachverständigenrat 1998, pp. 247-256). Rather than keeping the management of higher education institutions in 
the sole responsibility of the state, it seems that European systems of higher education could gain a lot in terms of efficiency by some measures of privatization (cf. Psacharopoulos 2005).

As part of market-based reforms, collecting tuition fees from students could increase the incentives for students to study more efficiently. If the beneficiaries of higher education had to make a greater private contribution to the costs, this could not only raise the efficiency of the use of their own time, but it could also create incentives for providers of higher education to use their resources more efficiently. In a European perspective, the internal market for higher education with mobility of students across the European Union can help to enact functioning competition in higher education where the markets in many European countries are too small to enable workable competition. At the same time, the mobility of students calls for some form of coordination of the policies of the member states of the European Union to ensure a proper matching of costs to beneficiaries.

\section{Equity:}

The shift in relative demand towards highly educated and skilled labour over the past decades, which seems to be mostly driven by skill-biased technological change, had major effects on the education structure of employment and educational wage differentials on the labour market (cf. Machin 2004; Cahuc and Zylberberg 2004, chapter 10). Largely unrelated to the education policies pursued, this shift has entailed an increase in overall inequality which manifested itself mainly in a strong increase in wage inequality in the United Kingdom (as well as the United States) and in a strong increase in relative unemployment of the low-skilled in Continental European countries. This suggests that inequalities in access to higher education translate into inequalities in economic outcomes in an ever stronger way.

In most current systems of higher education in Europe, equality of access is not achieved. In terms of financing, all tax-paying households contribute to the public financing of higher education in the standard tax-financed systems of European higher education. But in terms of access, in contrast to the compulsory levels of education, there is self-selection at the stage of higher education programmes in that children of academics are much more likely to go to university. As a consequence, unless there is very strong tax progression, tax funding may be viewed as unequal in that part of the funding may come from groups with little opportunities to access higher education (cf. Barr 2004; Psacharopoulos 2005). As argued above, the main reason for inequality in access is probably not that children from disadvantaged backgrounds cannot afford to go, but rather that they do not have the prerequisite educational qualifications. To alleviate this inequality in access, policy has to intervene much earlier. 
Otherwise, any policy that aims to increase participation in higher education could easily result in higher participation combined with increased inequity because it will be students from well-off families who increase participation, as has happened in the United Kingdom in the 1980s/90s (cf. Machin 2006). US evidence, while suggesting that financial aid schemes can have a significant effect on college attendance (although the effect on college completion is less clear), is also mixed on whether the effect of financial aid is larger or smaller for students from disadvantaged backgrounds (cf. Kane 1994; Dynarski 2003; and the review in Dynarski 2002).

Introducing tuition fees in the current setting without proper care for equity goals would probably aggravate the problem of unequal access to higher education - at least when equity is viewed in terms of the students' family background. Therefore, it seems critical from an equity perspective to provide proper financial means to able students from poor family backgrounds. An obvious solution is to defer the tuition fees by combining them with a system of income-contingent loans, which allow credit-constrained students to cover the fees. Income-contingent loans are loans that enable students to finance university education and that have to be paid only if and when the students have left university and earn an income above a specified threshold. For a proper functioning, such loans should be made available to all students and should cover cost of living in addition to tuition fees.

The fees could be selective rather than across the board. Students from low socio-economic backgrounds could receive targeted grants and scholarships, whereas students from well-off families would pay the full social cost of their study (cf., e.g., Acemoglu 2001 for a brief survey of possible equity-enhancing effects of means-tested subsidies to higher education). Subsidizing higher education conditional on parental income can be a useful component in an efficient design of overall redistribution policy (Dur et al. 2004). Because the substantial uncertainty of investments in higher education could discourage particularly disadvantaged students, the state could carry most of this uncertainty through the income contingency of the loans. In equity terms, the income contingency creates a built-in insurance against inability to repay the loan. Again, issues of implementation will determine the administrative costs of the system. From an international perspective, contracts should be set up to ensure repayment also if a student later emigrates (see Barr 2004 and Greenaway and Haynes 2004 for further details of how to design a system of fees with income-contingent loans).

Income-contingent loans can even be equity-enhancing when perceiving equity not in terms of family background, but of students' own lifetime well-being. This perspective seems to be a particularly relevant in higher education. As discussed above, there are substantial 
private returns to higher education, so that by its very attendance these students will be the economically better-off in the future. Therefore, it seems only right from an equity perspective that they should also make contributions to the cost of their higher education, at least at a time when their earnings are indeed high once they have entered the labour market.

\section{Complementarity or trade-off:}

In this perspective, both efficiency and equity considerations support a system of higher education where beneficiaries contribute tuition fees which they finance through incomecontingent loans (cf. Greenaway and Haynes 2003). Furthermore, fee and loan policies could be targeted specifically at students from poor family backgrounds to alleviate further equity concerns. By contrast, the state-run and state-financed way in which European higher education systems are currently set up makes them both inefficient and inequitable (cf. Psacharopoulos 2005). Thus, a policy of tuition fees coupled with income-contingent loans could create some complementarity between efficiency and equity in higher education. Similarly, if credit constraints were the main cause for unequal access, equitable policies which subsidize costs for students from low-income families would also be efficient, because they would enable high-ability students with high returns to obtain a higher education degree.

Still, in reality the main reason for unequal access to higher education lies mainly in a lack of prerequisites due to deficiencies at earlier stages of the education life cycle. In this case, there is indeed a trade-off between efficiency and equity in higher education, since it would be efficient to focus resources on those who are already advantaged. As has been seen in the past, policies that aim to increase participation in higher education in an effort to enhance equity can therefore end up raising inequity, because it is students from relatively well-off families who will disproportionately take up the new slots (cf. Machin 2006).

\subsection{Training and Lifelong Learning}

While the previously discussed education programmes mostly take place before students enter the labour market, this section discusses investments in training and lifelong learning that take place concurrent with or after some labour-market experience. Similar to the work-related programmes of vocational education discussed in Section 3.3, continuous training tends to provide specific skills, and the person to be educated decides on it jointly with the employer.

As in the case of higher education, the basis for addressing issues of efficiency and equity of education in adulthood, in terms of training and lifelong learning, is relatively thin. On the one hand, policy recommendations based on theory are ambiguous and depend crucially on 
the specific setting (cf. the recent survey by Leuven 2005). On the other hand, particularly in Europe, statistical data on training costs are rare, and information on training benefits in terms of productivity is limited (Bassanini et al. 2005), restraining a profound empirical analysis. But still, in particular in light of recent cross-European evidence on workplace training by Bassanini et al. (2005), some basic patterns and general results emerge.

\section{Efficiency:}

In terms of efficiency, a fundamental difference emerges between employer-provided workplace training and publicly provided training programmes, mostly for the unemployed. Workplace training provided by firms seems to be associated with substantial earnings returns, although distilling causality is particularly hard in this case (cf. chapter 4 of Bassanini et al. 2005 for a survey and own evidence). From a theoretical point, it is not clear whether the current institutional setup of European labour markets sets efficient incentives for investments in training. In competitive labour markets, firms have incentives to invest efficiently in firm-specific skills, while employees have incentives to invest efficiently in general skills (Becker 1964). In imperfect labour markets, by contrast, firms can also have incentives to sponsor general training, but underinvestment may still arise (cf. Acemoglu and Pischke 1999). Firms can also have incentives to finance the acquisition of general skills if different firms use the different general skills in different combinations and attach different weights to each of them (Lazear 2003b). Empirically, Bassanini et al. (2005) point out that there is no clear evidence for an under-provision of workplace training, so that the currently achieved level may not be too far from the socially efficient one in most European countries.

However, there is a clear pattern emerging that training by private firms goes mostly to the higher educated. Similar to previous research from the United States, Arulampalam et al. (2004a) and Bassanini et al. (2005) find that also in Europe, training increases with education and skill-intensity of occupations, as would be expected from the skill multiplier effects discussed in Section 2.1. This suggests that the rates of return to training seem to be highest for people who already have high education - either because the benefits are higher or because the costs are lower - so that an efficient allocation of investment in training would go to those who are already high-skilled. By contrast, rates of return to training investments might be particularly low for the disadvantaged. Oosterbeek (1998) presents Dutch evidence suggesting that this pattern reflects indeed differing net benefits for workers of different education levels, rather than firms favouring different workers differently. 
A role for the state in furthering the efficiency of training systems might lie in improving information about training opportunities, setting appropriate legal frameworks and ensuring portability of skills (Bassanini et al. 2005). State regulation could also help by monitoring the quality of training programmes and certifying skills, which could facilitate contracting between firms and employees at the individual level. However, in theory such measures can also be counter-productive, and detailed empirical evidence on the efficiency effects of state regulation of training programmes is still missing (cf. Acemoglu and Pischke 1999).

In contrast to employer-provided workplace training, the track record of the efficiency of public sector training programmes, usually devised as part of active labour market policies, is far bleaker (cf. Heckman et al. 1999 for a general survey of US evidence and Heckman 2000 for a survey of failed training programmes in the United States). Evaluation studies of public training programmes in European countries, including France, Germany, Ireland, Norway, Poland, the Slovak Republic, Sweden and the United Kingdom, tend to report very low or even negative returns, in the sense that the costs of the programmes are significantly higher than the benefits in terms of increased earnings or employment probabilities (cf., e.g., the surveys by Martin and Grubb 2001 and Kluve and Schmidt 2002). Often, it is hard to identify any significant positive effect of public training programmes on earnings and employability (cf. Fitzenberger and Prey 2000 and Lechner 2000 for examples from East Germany). There are even cases where significant negative effects of public sector sponsored training on earnings and employability of participants have been found, at least in the short run, although more recent evidence suggests that effects in the longer run may be not as bleak, albeit probably far from being cost effective (cf. Lechner et al. 2004 and the references therein for evidence from West Germany).

Thus, training schemes devised by the state seem to be mostly ineffective and remote from cost effectiveness. Still, effects can vary substantially between different groups. Broadly speaking, public sector training programmes have been found to be more effective for adult women than for adult men and youth (cf. Heckman 2000; Kluve and Schmidt 2002). But quite generally, evidence from the United Kingdom suggests that lifelong learning has very little directly measurable labour-market effects (cf. Machin and Vignoles 2005), although there may be some effects for the most disadvantaged (Jenkins et al. 2002).

Together, the evidence suggests that programmes of training and lifelong learning should be related to and thus produced on the job. Therefore, encouraging the private sector, which is better aware of market demands, to produce additional training seems better policy than direct public production of training (cf. Heckman 2000; Kluve and Schmidt 2002). 


\section{Equity:}

In terms of equity, publicly provided training programmes often target the unemployed, which would seem highly welcome from an equity perspective. However, the evidence just discussed that these programmes are not effective in most cases suggests that they in effect do not strongly advance the cause of equity. Among targeted public sector training programmes, US evidence suggests that results for programmes aimed at displaced workers are often discouraging (cf. Heckman 2000). But there is some European evidence suggesting that programmes targeted at the disadvantaged can help to improve their labour-market outcomes (cf. Kluve and Schmidt 2002).

The fact that firm-provided workplace training tends to be confined to the high-skilled suggests that this kind of training tends to hinder rather than advance equity causes. In terms of equality of opportunity, public interventions might be justified if circumstances out of the reach of individuals, such as their family background, prevent them from obtaining additional training. While in the United States, the provision of company training is negatively associated with family background once education and ability are controlled for (cf. Carneiro and Heckman 2003), Bassanini et al. (2005) find that training outcomes in Europe are significantly affected by parental background even after controlling for education, in particular in Southern European countries. Given data restrictions, the extent to which this result is robust, and the extent to which public policies might be able to affect it, remains an open question. Because equality of opportunity is not necessarily a goal of private firms, Bassanini et al. (2005) stress that public training policies that try to address equity issues should be targeted at individuals rather than firms.

There are two features that make this relatively negative equity assessment of training programmes slightly more positive. First, the perspective taken in this paper, recommending that skill deficiencies of the disadvantaged should be remedied as early as possible, is very long-run. In particular, this perspective misses those who currently have already left the phase of compulsory education with a low level of skills. Especially when taking the view that equity is not just about money transfers but also about social inclusion, which may mean that working carries intrinsic individual dignity that should be valued as a means against a culture of dependence, the relative preference for targeted training policies over other equity policies increases. In many cases, it may still be more cost effective to subsidize jobs rather than to spend the money on investments in lifelong learning. But in this perspective, it is particularly noteworthy that among the different active labour market policies, training programmes seem to be more effective than subsidy-type programmes (Kluve and Schmidt 2002). Thus, policies 
that encourage training may in many instances still be the best available option to increase the fates of currently low-qualified adults, helping them find work and earn income. In terms of implementation, for such policies to be successful it seems important that they aim at encouraging the private sector to provide training, while the government can help through skill certification and quality monitoring, rather than at direct training provision by the public sector (cf. Acemoglu 2001; Heckman 2000).

Second, when combining the life cycle perspective with the fact that family background is a crucial input into early learning and child development, lifelong learning activities aimed at young parents may carry the additional benefit of improving the early educational environments for children from otherwise disadvantaged backgrounds. Educational involvement of low-educated parents during adulthood can reap the intergenerational gains of improved early learning of their children, with all its subsequent dynamic effects (cf. Section 2.1 above), by improving the educational background of families. Unfortunately, empirical knowledge about the extent to which such educational interventions at the parental level, like the national plan targeted at illiterate parents in Italy in the 1970s, can be effective in an intertemporal sense is largely missing.

\section{Complementarity or trade-off:}

Despite these countervailing features, the basic facts remain that returns to training seem highest for the well-educated and public training schemes aimed at low-skilled workers have proven to be quite ineffective. Therefore, in general there seems to be a trade-off between efficiency and equity at this late stage of the education life cycle. In adult training and lifelong learning, it seems that returns are highest for those who have already obtained high degrees of education. By contrast, policies that try to target programmes of training and lifelong learning at disadvantaged people run into the problem that the returns to these late investments may be particularly low among the disadvantaged, so that alternative redistributive policies may be more efficient (cf., e.g., Bassanini et al. 2005). Therefore, it seems crucial that policies targeted at equity set in much earlier, trying to improve the access to high-quality early childhood and school education for students from disadvantaged families.

\section{Conclusion}

Ideally, a sound assessment of investment priorities at the margin would have to be established on the basis of country-specific empirical assessments. Lacking encompassing assessments for most European countries, it is still possible based on the available empirical 
evidence to arrive at a broad pattern of priorities for educational investments as depicted in Figure 1. The overall assessment of efficiency and equity in European education and training systems suggests that there seem to be strong complementarities between efficiency and equality of opportunity in policies that act at early stages of the education process. However, these seem to turn into trade-offs between efficiency and equity at late stages of the education life cycle. Thus, the earlier equity- and efficiency-enhancing policies set in, the better. If European countries focus public investments early on, improving the fates of disadvantaged students in early childhood and at the school level, then they do not necessarily have to choose between efficiency and equity. Only if they wait until students reach the age to enter higher education or even adult training and lifelong learning, their attempts to foster equity sometimes end up being both inefficient and unfair.

Within the different stages of the education and training system, the evidence suggests that the technical efficiency in educating both the disadvantaged and the student population at large can best be promoted by leaving behind a simple input orientation in favour of an output orientation. Such an output orientation can be achieved through institutional reforms that focus incentives on the performance of students. By setting clear standards and monitoring their achievement, while at the same time using the forces of choice and competition to find the best ways of how to achieve the output goals, public policies can best ensure that every person gets decent education and training.

Of course, as this paper has discussed in detail, the specific implementation of such policy features will be different for each stage of the education cycle. At the stage of early childhood education, an implementation aimed at educational intensity and accountability seems advisable. In schools, combining accountability with autonomy and competition with public funding, as well as setting performance-related rewards for teachers and de-tracking schools, seem well-suited to advance efficiency and equity, especially when designed to target disadvantaged students. Private competition coupled with tuition fees and income-contingent loans designed also to help the most disadvantaged are recommendable features in higher education, while competitive private provision on the job oriented towards market needs, combined with public certification and quality monitoring, seem key in vocational education, training and lifelong learning. In each case, policymakers have to take caution in designing and implementing such output-oriented reforms in ways that induce proper and fair incentives for all agents. By doing so, public policies can establish education and training systems that can get very far in being both efficient and equitable at the same time. Given the importance of education and training for the long-run economic and social well-being of individuals and 
societies alike, such policies could also go a long way towards reaching goals of future economic and social prosperity in Europe.

However, an important caveat is in order about these overall assessments of education and training policies in Europe. Currently, far too little is known on the specifics of equity and efficiency of different European programmes because of severe lacks of appropriate data and rigorous empirical evaluation studies. This is particularly true for the details on how to best advance learning in early childhood and how early advancements are sustained through the life cycle, but also more generally at other stages of education and training. The particularly positive assessment of early interventions may be based on too little and specific empirical evidence which may not translate into very general findings in the end. Analyses that confront the benefits of specific interventions with their costs are mostly missing in Europe.

To be able to implement better-informed policies to foster equity and efficiency in education and training, European countries will have to design policy interventions in ways that are amenable to rigorous empirical evaluation, collect the necessary data on inputs and outcomes and implement independent evaluation studies that create knowledge on what works and what does not. Such country-specific empirical assessments will be able to provide particularly useful and robust findings if evaluators are involved in designing the policy ex ante, in order to set up a convincing evaluation design. There could also be scope for ensuring that country-specific assessments are done in as standardised a way as possible to facilitate learning across European systems, in particular when European institutions set up Europewide research projects on international comparisons. Such an improved management of policy innovations would enable a process of continuous learning and adaptation in European education and training that could ultimately contribute much more to the causes of equity and efficiency than many policy interventions have done in the past. 


\section{References}

Acemoglu, Daron (2001). Human Capital Policies and the Distribution of Income: A Framework for Analysis and Literature Review. New Zealand Treasury Working Papers 01/03. Wellington: The Treasury.

Acemoglu, Daron, Jörn-Steffen Pischke (1999). Beyond Becker: Training in Imperfect Labour Markets. Economic Journal 109 (453): F112-F142.

Altonji, Joseph G., Charles R. Pierret (2001). Employer Learning and Statistical Discrimination. Quarterly Journal of Economics 116 (1): 313-350.

Ammermüller, Andreas (2005). Educational Opportunities and the Role of Institutions. ZEW Discussion Paper 05-44. Mannheim: Centre for European Economic Research.

Arrow, Kenneth, Samuel Bowles, Steven Durlauf, eds. (2000). Meritocracy and Economic Inequality. Princeton, NJ: Princeton University Press.

Arulampalam, Wiji, Mark L. Bryan, Alison L. Booth (2004a). Training in Europe. Journal of the European Economic Association 2 (2-3): 346-360.

Arulampalam, Wiji, Robin A. Naylor, Jeremy P. Smith (2004b). A Hazard Model of the Probability of Medical School Drop-out in the UK. Journal of the Royal Statistical Society Series A 167 (1): 157-178.

Atkinson, Adele, Simon Burgess, Bronwyn Croxson, Paul Gregg, Carol Propper, Helen Slater, Deborah Wilson (2004). Evaluating the Impact of Performance-related Pay for Teachers in England. CMPO Working Paper 04/113. Bristol: Centre for Market and Public Organisation.

Barnett, W. Steven (1992). Benefits of Compulsory Preschool Education. Journal of Human Resources 27 (2): 279-312.

Barnett, W. Steven (1995). Long-Term Effects of Early Childhood Programs on Cognitive and School Outcomes. The Future of Children 5 (3): 25-50.

Barr, Nicholas (2004). Higher Education Funding. Oxford Review of Economic Policy 20 (2): 264-283.

Barro, Robert J. (2001). Human Capital and Growth. American Economic Review 91 (2): 1217.

Bassanini, Andrea, Alison Booth, Giorgio Brunello, Maria De Paola, Edwin Leuven (2005). Workplace Training in Europe. IZA Discussion Paper 1640. Bonn: Institute for the Study of Labor.

Bauer, Philipp, Regina T. Riphahn (2006). Timing of School Tracking as a Determinant of Intergenerational Transmission of Education. Economics Letters 91 (1): 90-97.

Becker, Gary S. (1964/1993). Human Capital: A Theoretical and Empirical Analysis, with Special Reference to Education. Third Edition. Chicago: University of Chicago Press.

Belfield, Clive R., Milagros Nores, Steve Barnett, Lawrence Schweinhart (2006). The High/Scope Perry Preschool Program. Journal of Human Resources 41 (1): 162-190.

Bénabou, Roland, Francis Kramarz, Corinne Prost (2004). Zones d'éducation prioritaire: quels moyens pour quels résultats? Une évaluation sur la période 1982-1992. Économie et Statistique (380): 3-29. 
Betts, Julian R. (1998). The Impact of Educational Standards on the Level and Distribution of Earnings. American Economic Review 88 (1): 266-275.

Betts, Julian R., Tom Loveless, eds. (2005). Getting Choice Right: Ensuring Equity and Efficiency in Education Policy. Washington, D.C.: Brookings Institution Press.

Betts, Julian R., John E. Roemer (2006). Equalizing Opportunity for Racial and Socioeconomic Groups in the United States Through Educational Finance Reform. Forthcoming in: Ludger Wößmann, Paul E. Peterson (eds.), Schools and the Equal Opportunity Problem. Cambridge, MA: MIT Press.

Bishop, John H. (1989). Is the Test Score Decline Responsible for the Productivity Growth Decline? American Economic Review 79 (1): 178-197.

Bishop, John H. (1992). The Impact of Academic Competencies on Wages, Unemployment, and Job Performance. Carnegie-Rochester Conference Series on Public Policy 37: 127-194.

Bishop, John H. (1994). The Impact of Previous Training on Productivity and Wages. In: Lisa M. Lynch (ed.), Training and the Private Sector: International Comparisons: 161-199. NBER Comparative Labor Markets Series. Chicago: University of Chicago Press.

Bishop, John H. (1997). The Effect of National Standards and Curriculum-Based Exams on Achievement. American Economic Review 87 (2): 260-264.

Bishop, John H. (2006). Drinking from the Fountain of Knowledge: Student Incentive to Study and Learn. Forthcoming in: Eric A. Hanushek, Finis Welch (eds.), Handbook of the Economics of Education. Amsterdam: North-Holland.

Bishop, John H., Ludger Wößmann (2004). Institutional Effects in a Simple Model of Educational Production. Education Economics 12 (1): 17-38.

Björklund, Anders, Per-Anders Edin, Peter Freriksson, Alan Krueger (2004). Education, Equality and Efficiency: An Analysis of Swedish School Reforms during the 1990s. IFAU Report 2004:1. Uppsala: Institute for Labour Market Policy Evaluation.

Blau, David, Janet Currie (2006). Preschool, Day Care, and Afternoon Care: Who's Minding the Kids? Forthcoming in: Eric A. Hanushek, Finis Welch (eds.), Handbook of the Economics of Education. Amsterdam: North-Holland. (available as NBER Working Paper 10670, Cambridge, MA: National Bureau of Economic Research, 2004)

Bonesrønning, Hans, Torberg Falch, Bjarne Strøm (2005). Teacher Sorting, Teacher Quality, and Student Composition. European Economic Review 49 (2): 457-483.

Bonnal, Liliane, Sylvie Mendes, Catherine Sofer (2002). School-to-Work Transition: Apprenticeship versus Vocational School in France. International Journal of Manpower 23 (5): 426-442.

Bradley, Steve, Jim Taylor (2004). The Economics of Secondary Schooling. In: Geraint Johnes, Jill Johnes (eds.), International Handbook on the Economics of Education. Cheltenham: Edward Elgar.

Büchel, Felix (2002). Successful Apprenticeship-to-Work Transitions: On the Long-term Change in Significance of the German School-leaving Certificate. International Journal of Manpower 23 (5): 394-410.

Burgess, Simon, Brendon McConnell, Carol Propper, Deborah Wilson (2006). The Impact of School Choice on Sorting by Ability and Socio-economic Factors in English Secondary Education. Forthcoming in: Ludger Wößmann, Paul E. Peterson (eds.), Schools and the Equal Opportunity Problem. Cambridge, MA: MIT Press. 
Cahuc, Pierre, André Zylberberg (2004). Labor Economics. Cambridge, MA: MIT Press.

Calmfors, Lars, Giancarlo Corsetti, Seppo Honkapohja, John Kay, Gilles Saint-Paul, HansWerner Sinn, Jan-Egbert Sturm, Xavier Vives (2006). Report on the European Economy 2006. Munich: EEAG European Economic Advisory Group at CESifo.

Card, David (1999). The Causal Effect of Education on Earnings. In: Orley Ashenfelter, David Card (eds.), Handbook of Labor Economics, Volume 3A: 1801-1863. Amsterdam: North-Holland.

Carneiro, Pedro, James J. Heckman (2003). Human Capital Policy. In: James J. Heckman, Alan B. Krueger, Inequality in America: What Role for Human Capital Policies?. Cambridge, MA: MIT Press. (also available as NBER Working Paper 9495, Cambridge, MA: National Bureau of Economic Research)

Clark, Damon, René Fahr (2002). The Promise of Workplace Training for Non-College Bound Youth: Theory and Evidence from German Apprenticeship. CEP Discussion Paper 528. London: Centre for Economic Performance, London School of Economics.

Cunha, Flavio, James J. Heckman, Lance Lochner, Dimitriy V. Masterov (2006). Interpreting the Evidence on Life Cycle Skill Formation. Forthcoming in: Eric A. Hanushek, Finis Welch (eds.), Handbook of the Economics of Education. Amsterdam: North-Holland. (available as NBER Working Paper 11331, Cambridge, MA: National Bureau of Economic Research, 2005)

Currie, Janet (2001). Early Childhood Education Programs. Journal of Economic Perspectives 15 (2): 213-238.

Currie, Janet, Duncan Thomas (2001). Early Test Scores, School Quality and SES: Longrun Effects on Wage and Employment Outcomes. Research in Labor Economics 20: 103-132.

de la Fuente, Angel, Rafael Doménech (2006). Human Capital in Growth Regressions: How Much Difference Does Data Quality Make? Journal of the European Economic Association 4 (1): 1-36.

Dur, Robert, Coen Teulings, Thijs van Rens (2004). Should Higher Education Subsidies Depend on Parental Income? Oxford Review of Economic Policy 20 (2): 284-297.

Dustmann, Christian (2004). Parental Background, Secondary School Track Choice, and Wages. Oxford Economic Papers 56 (2): 209-230.

Dynarski, Susan M. (2002). The Behavioral and Distributional Implications of Aid for College. American Economic Review 92 (2): 279-285.

Dynarski, Susan M. (2003). Does Aid Matter? Measuring the Effect of Student Aid on College Attendance and Completion. American Economic Review 93 (1): 279-288.

Eide, Eric, Dan Goldhaber, Dominic Brewer (2004). The Teacher Labour Market and Teacher Quality. Oxford Review of Economic Policy 20 (2): 230-244.

European Commission (2006). Time to Move up a Gear: The European Commission's 2006 Annual Progress Report on Growth and Jobs. Brussels. (europa.eu.int/growthandjobs/annualreport_en.htm)

European Council (2006). Presidency Conclusions of the Brussels European Council (23/24 March 2006): The Relaunched Lisbon Strategy for Jobs and Growth. Brussels. (europa.eu/european_council/conclusions/index_en.htm) 
Euwals, Rob, Rainer Winkelmann (2004). Training Intensity and First Labor Market Outcomes of Apprenticeship Graduates. International Journal of Manpower 25 (5): 447-462.

Feinstein, Leon (2003). Inequality in the Early Cognitive Development of British Children in the 1970 Cohort. Economica 70 (1): 73-97.

Feinstein, Leon (2004). Mobility in Pupils' Cognitive Attainment During School Life. Oxford Review of Economic Policy 20 (2): 213-229.

Feinstein, Leon, Donald Robertson, James Symons (1999). Pre-School Education and Attainment in the National Child Development Study and British Cohort Study. Education Economics 7 (3): 209-234.

Figlio, David N., Maurice E. Lucas (2004). Do High Grading Standards Affect Student Performance? Journal of Public Economics 88 (9): 1815-1834.

Filer, Randall K., Daniel Münich (2003). Responses of Private and Public Schools to Voucher Funding. Paper presented at the Annual Meeting of the American Economic Association in Washington, D.C.

Fitzenberger, Bernd, Hedwig Prey (2000). Evaluating Public Sector Sponsored Training in East Germany. Oxford Economic Papers 52 (3): 497-520.

Franz, Wolfgang, David Soskice (1995). The German Apprenticeship System. In: Friedrich Buttler, Wolfgang Franz, Ronald Schettkat, David Soskice (eds.), Institutional Frameworks and Labor Market Performance: Comparative Views on the U.S. and German Economies: 208-234. London: Routledge.

Fuchs, Thomas, Ludger Wößmann (2004). Governance and Primary-School Performance: International Evidence. Ifo Institute for Economic Research at the University of Munich, mimeo.

Garces, Eliana, Duncan Thomas, Janet Currie (2002). Longer-Term Effects of Head Start. American Economic Review 92 (4): 999-1012.

Goodman, Alissa, Barbara Sianesi (2005). Early Education and Children's Outcomes: How Long Do the Impacts Last? Fiscal Studies 26 (4): 513-548.

Greenaway, David, Michelle Haynes (2003). Funding Higher Education in the UK: The Role of Fees and Loans. Economic Journal 113 (485): F150-F166.

Greenaway, David, Michelle Haynes (2004). Funding Higher Education. In: Geraint Johnes, Jill Johnes (eds.), International Handbook on the Economics of Education. Cheltenham: Edward Elgar.

Grossman, Michael (2006). Education and Nonmarket Outcomes. Forthcoming in: Eric A. Hanushek, Finis Welch (eds.), Handbook of the Economics of Education. Amsterdam: NorthHolland. (available as NBER Working Paper 11582, Cambridge, MA: National Bureau of Economic Research, 2005)

Gundlach, Erich, Ludger Wößmann, Jens Gmelin (2001). The Decline of Schooling Productivity in OECD Countries. Economic Journal 111 (471): C135-C147.

Hanushek, Eric A. (2003). The Failure of Input-Based Schooling Policies. Economic Journal 113 (485): F64-F98.

Hanushek, Eric A. (2006). Some U.S. Evidence on How the Distribution of Educational Outcomes Can Be Changed. Forthcoming in: Ludger Wößmann, Paul E. Peterson (eds.), Schools and the Equal Opportunity Problem. Cambridge, MA: MIT Press. 
Hanushek, Eric A., with co-authors (1994). Making Schools Work: Improving Performance and Controlling Costs. Washington, D.C.: Brookings Institution Press.

Hanushek, Eric A., John F. Kain, Steven G. Rivkin, Gregory F. Branch (2005). Charter School Quality and Parental Decision Making with School Choice. NBER Working Paper 11252. Cambridge, MA: National Bureau of Economic Research.

Hanushek, Eric A., Dennis D. Kimko (2000). Schooling, Labor-Force Quality, and the Growth of Nations. American Economic Review 90 (5): 1184-1208.

Hanushek, Eric A., Margaret E. Raymond (2004). The Effect of School Accountability Systems on the Level and Distribution of Student Achievement. Journal of the European Economic Association 2 (2-3): 406-415.

Hanushek, Eric A., Ludger Wößmann (2006). Does Early Tracking Affect Educational Inequality and Performance? Differences-in-Differences Evidence across Countries. Economic Journal 116 (510): C63-C76.

Harmon, Colm, Hessel Oosterbeek, Ian Walker (2003). The Returns to Education: Microeconomics. Journal of Economic Surveys 17 (2): 115-155.

Heckman, James J. (2000). Policies to Foster Human Capital. Research in Economics 54 (1): 3-56.

Heckman, James J., Robert LaLonde, Jeffrey A. Smith, (1999). The Economics and Econometrics of Active Labor Market Programs. In: Orley Ashenfelter, David Card (eds.), Handbook of Labor Economics, Volume 3A: 1865-2097. Amsterdam: North-Holland.

Hoxby, Caroline M. (2000). Does Competition among Public Schools Benefit Students and Taxpayers? American Economic Review 90 (5): 1209-1238.

Hoxby, Caroline M. (2002). Would School Choice Change the Teaching Profession? Journal of Human Resources 37 (4): 846-891.

Hoxby, Caroline M., ed. (2003a). The Economics of School Choice. A National Bureau of Economic Research Conference Report. Chicago: University of Chicago Press.

Hoxby, Caroline M. (2003b). School Choice and School Competition: Evidence from the United States. Swedish Economic Policy Review 10 (3): 9-65.

Hoxby, Caroline M., Andrew Leigh (2004). Pulled Away or Pushed Out? Explaining the Decline of Teacher Aptitude in the United States. American Economic Review 94 (2): 236240 .

Jacob, Brian A. (2005). Accountability, Incentives and Behavior: The Impact of High-stakes Testing in the Chicago Public Schools. Journal of Public Economics 89 (5-6): 761-796.

Jacob, Brian A., Steven D. Levitt (2003). Rotten Apples: An Investigation of the Prevalence and Predictors of Teacher Cheating. Quarterly Journal of Economics 118 (3): 843-877.

Jenkins, Andrew, Anna Vignoles, Alison Wolf, Fernando Galindo-Rueda (2002). The Determinants of Effects of Lifelong Learning. CEE Discussion Paper 19. London: Centre for the Economics of Education, London School of Economics.

Jürges, Hendrik, Kerstin Schneider, Felix Büchel (2005). The Effect of Central Exit Examinations on Student Achievement: Quasi-Experimental Evidence from TIMSS Germany. Journal of the European Economic Association 3 (5): 1134-1155. 
Kamerman, Sheila B., Michelle Neuman, Jane Waldfogel, Jeanne Brooks-Gunn (2003). Social Policies, Family Types and Child Outcomes in Selected OECD Countries. OECD Social, Employment and Migration Working Paper 6. Paris: OECD.

Kane, Thomas J. (1994). College Entry by Blacks since 1970: The Role of College Costs, Family Background, and the Returns to Education. Journal of Political Economy 102 (5): 878-911.

Kane, Thomas J., Douglas O. Staiger (2002). The Promise and Pitfalls of Using Imprecise School Accountability Measures. Journal of Economic Perspectives 16 (4): 91-114.

Kluve, Jochen, Christoph M. Schmidt (2002). Can Training and Employment Subsidies Combat European Unemployment? Economic Policy 17 (35): 410-448.

Krueger, Alan B. (1999). Experimental Estimates of Education Production Functions. Quarterly Journal of Economics 114 (2): 497-532.

Krueger, Alan B., Mikael Lindahl (2001). Education for Growth: Why and For Whom? Journal of Economic Literature 39 (4): 1101-1136.

Krueger, Dirk, Krishna B. Kumar (2004). US-Europe Differences in Technology-Driven Growth: Quantifying the Role of Education. Journal of Monetary Economics 51 (1): 161-190.

Ladd, Helen F. (2002). School Vouchers: A Critical View. Journal of Economic Perspectives 16 (4): 3-24.

Ladd, Helen F., Randall P. Walsh (2002). Implementing Value-Added Measures of School Effectiveness: Getting the Incentives Right. Economics of Education Review 21 (1): 1-17.

Lauer, Charlotte, Viktor Steiner (2000). Returns to Education in West Germany: An Empirical Assessment. ZEW Discussion Paper 00-04. Mannheim: Centre for European Economic Research.

Lavy, Victor (2002). Evaluating the Effect of Teachers' Group Performance Incentives on Pupil Achievement. Journal of Political Economy 110 (6): 1286-1317.

Lavy, Victor (2004). Performance Pay and Teachers' Effort, Productivity and Grading Ethics. NBER Working Paper 10622. Cambridge, MA: National Bureau of Economic Research.

Lazear, Edward P. (2003a). Teacher Incentives. Swedish Economic Policy Review 10 (3): $179-214$.

Lazear, Edward P. (2003b). Firm-Specific Human Capital: A Skill-Weights Approach. NBER Working Paper 9679. Cambridge, MA: National Bureau of Economic Research.

Lechner, Michael (2000). An Evaluation of Public-Sector-Sponsored Continuous Vocational Training Programs in East Germany. Journal of Human Resources 35 (2): 347-375.

Lechner, Michael, Ruth Miguel, Conny Wunsch (2004). Long-run Effects of Public Sector Sponsored Training in West Germany. IZA Discussion Paper 1443. Bonn: Institute for the Study of Labor.

Leney, Tom, with consortium partners (2004). Achieving the Lisbon Goal: The Contribution of VET. Final Report to the European Commission. Brussels: European Commission.

Leuven, Edwin (2005). The Economics of Private Sector Training: A Survey of the Literature. Journal of Economic Surveys 19 (1): 91-111. 
Leuven, Edwin, Hessel Oosterbeek (2006). The Effectiveness of Human Capital Policies for Disadvantaged Groups in the Netherlands. Forthcoming in: Ludger Wößmann, Paul E. Peterson (eds.), Schools and the Equal Opportunity Problem. Cambridge, MA: MIT Press.

Leuven, Edwin, Mikael Lindahl, Hessel Oosterbeek, Dinand Webbink (2004). New Evidence on the Effect of Time in School on Early Achievement. Scholar Working Paper 47/04. Amsterdam: Research Institute Scholar.

Levaciić, Rosalind (2004). Competition and the Performance of English Secondary Schools: Further Evidence. Education Economics 12 (2): 177-193.

Lochner, Lance, Enrico Moretti (2004). The Effect of Education on Crime: Evidence from Prison Inmates, Arrests, and Self-Reports. American Economic Review 94 (1): 155-189.

Lowry, Robert C. (2004). Markets, Governance, and University Priorities: Evidence on Undergraduate Education and Research. Economics of Governance 5 (1): 29-51.

Lynch, Lisa M. (1994). Introduction. In: Lisa M. Lynch (ed.), Training and the Private Sector: International Comparisons: 1-24. NBER Comparative Labor Markets Series. Chicago: University of Chicago Press.

Machin, Stephen J. (2004). Skill-biased Technical Change and Educational Outcomes. In: Geraint Johnes, Jill Johnes (eds.), International Handbook on the Economics of Education. Cheltenham: Edward Elgar.

Machin, Stephen J. (2006). Education Expansion and Intergenerational Mobility in Britain. Forthcoming in: Ludger Wößmann, Paul E. Peterson (eds.), Schools and the Equal Opportunity Problem. Cambridge, MA: MIT Press.

Machin, Stephen J., Anna Vignoles, eds. (2005). What's the Good of Education? The Economics of Education in the UK. Princeton University Press.

Magnuson, Katherine A., Christopher J. Ruhm, Jane Waldfogel (2004). Does Prekindergarten Improve School Preparation and Performance? NBER Working Paper 10452. Cambridge, MA: National Bureau of Economic Research.

Martin, John P., David Grubb (2001). What Works and For Whom: A Review of OECD Countries' Experience with Active Labour Market Policies. Swedish Economic Policy Review 8 (2): 9-56.

McIntosh, Steven, Anna Vignoles (2001). Measuring and Assessing the Impact of Basic Skills on Labour Market Outcomes. Oxford Economic Papers 53 (3): 453-481.

McMahon, Walter W. (2004). The Social and External Benefit of Education. In: Geraint Johnes, Jill Johnes (eds.), International Handbook on the Economics of Education. Cheltenham: Edward Elgar.

Milligan, Kevin, Enrico Moretti, Philip Oreopoulos (2004). Does Education Improve Citizenship? Evidence from the United States and the United Kingdom. Journal of Public Economics 88 (9): 1667-1695.

Muehlemann, Samuel, Juerg Schweri, Rainer Winkelmann, Stefan C. Wolter (2005). A Structural Model of Demand for Apprentices. CESifo Working Paper 1417. Munich: CESifo.

Murnane, Richard J., John B. Willett, Frank Levy (1995). The Growing Importance of Cognitive Skills in Wage Determination. Review of Economics and Statistics 77 (2): 251-266.

Neal, Derek A. (1997). The Effects of Catholic Secondary Schooling on Secondary Achievement. Journal of Labor Economics 15 (1): 98-123. 
Neal, Derek A. (2002). How Vouchers Could Change the Market for Education. Journal of Economic Perspectives 26 (4): 25-44.

Neal, Derek A., William R. Johnson (1996). The Role of Premarket Forces in Black-White Wage Differences. Journal of Political Economy 104 (5): 869-895.

Nechyba, Thomas J. (2000). Mobility, Targeting, and Private-School Vouchers. American Economic Review 90 (1): 130-146.

Nickell, Stephen (2004). Poverty and Worklessness in Britain. Economic Journal 114 (494): C1-C25.

Oosterbeek, Hessel (1998). Unravelling Supply and Demand Factors in Work-Related Training. Oxford Economic Papers 50 (2): 266-283.

Organisation for Economic Co-operation and Development (OECD) (2000). Literacy in the Information Age: Final Report of the International Adult Literacy Survey. Paris: OECD.

Organisation for Economic Co-operation and Development (OECD) (2004). Early Childhood Education and Care Policy in the Federal Republic of Germany. Paris: OECD.

Organisation for Economic Co-Operation and Development (OECD) (2005a). Education at a Glance: OECD Indicators 2005. Paris: OECD.

Organisation for Economic Co-Operation and Development (OECD) (2005b). Teachers Matter: Attracting, Developing and Retaining Effective Teachers. Paris: OECD.

Peterson, Paul E., William G. Howell, Patrick J. Wolf, David E. Campbell (2003). School Vouchers: Results from Randomized Experiments. In: Caroline M. Hoxby (ed.), The Economics of School Choice: 107-144. Chicago: University of Chicago Press.

Psacharopoulos, George (1991). Vocational Education Theory, Voced 101: Including Hints for 'Vocational Planners'. International Journal of Educational Development 11 (3): 193-199.

Psacharopoulos, George (1994). Returns to Investment in Education: A Global Update. World Development 22 (9): 1325-1343.

Psacharopoulos, George (2005). Why Some University Systems Are Collapsing: Realities from Europe. Paper presented at the conference 'The Future of the University', Vienna.

Psacharopoulos, George, Harry A. Patrinos (2004). Returns to Investment in Education: A Further Update. Education Economics 12 (2): 111-134.

Rivkin, Steven G., Eric A. Hanushek, John F. Kain (2005). Teachers, Schools, and Academic Achievement. Econometrica 73 (2): 417-458.

Roemer, John E. (1998). Equality of Opportunity. Cambridge, MA: Harvard University Press.

Ryan, Paul (1998). Is Apprenticeship Better? A Review of the Economic Evidence. Journal of Vocational Education and Training 50 (2): 289-325.

Ryan, Paul (2001). The School-to-Work Transition: A Cross-National Perspective. Journal of Economic Literature 39 (1): 34-92.

Sachverständigenrat zur Begutachtung der gesamtwirtschaftlichen Entwicklung (1998). Vor weitreichenden Entscheidungen - Jahresgutachten 1998/99. (German Council of Economic Experts, Annual Report 1998/99). Metzler-Poeschel, Stuttgart.

Sandström, F. Mikael, Fredrik Bergström (2005). School Vouchers in Practice: Competition Will Not Hurt You. Journal of Public Economics 89 (2-3): 351-380. 
Sapir, André, Philippe Aghion, Giuseppe Bertola, Martin Hellwig, Jean Pisani-Ferry, Dariusz Rosati, José Viñals, Helen Wallace (2003). An Agenda for a Growing Europe: Making the EU Economic System Deliver. Report of an Independent High-Level Study Group established on the initiative of the President of the European Commission. Brussels.

Schütz, Gabriela, Heinrich W. Ursprung, Ludger Wößmann (2005). Education Policy and Equality of Opportunity. CESifo Working Paper 1518. Munich: CESifo.

Schweinhart, Lawrence J., J. Montie, Z. Xiang, W.S. Barnett, C.R. Belfield, M. Nores (2005). Lifetime Effects: The High/Scope Perry Preschool Study Through age 40. Monographs of the High/Scope Educational Research Foundation, 14. Ypsilanti, MI: High/Scope Press.

Shleifer, Andrei (1998). State versus Private Ownership. Journal of Economic Perspectives 12 (4): 133-150.

Smith, Jeremy, Robin Naylor (2001). Determinants of Degree Performance in UK Universities: A Statistical Analysis of the 1993 Student Cohort. Oxford Bulletin of Economics and Statistics 63 (1): 29-60.

Steedman, Hilary (1993). The Economics of Youth Training in Germany. Economic Journal 103 (420): 1279-1291.

Tyler, John H., Richard J. Murnane, John B. Willett (2000). Do the Cognitive Skills of School Dropouts Matter in the Labor Market? Journal of Human Resources 35 (4): 748-754.

Vandenbussche, Jérôme, Philippe Aghion, Costas Meghir (2004). Growth, Distance to Frontier and Composition of Human Capital. Harvard University, mimeo.

West, Martin R., Paul E. Peterson (2006). The Efficacy of Choice Threats within School Accountability Systems: Results from Legislatively-Induced Experiments. Economic Journal 116 (510): C46-C62.

Wolfe, Barbara, Robert Haveman (2000). Accounting for the Social and Non-market Benefits of Education. Mimeo, OECD Workshop. Paris: OECD.

Wolter, Stefan C., Samuel Mühlemann, Jürg Schweri (2006). Why Some Firms Train Apprentices and Many Others Not. German Economic Review: forthcoming.

Wößmann, Ludger (2002). Schooling and the Quality of Human Capital. Berlin: Springer.

Wößmann, Ludger (2003). Schooling Resources, Educational Institutions and Student Performance: The International Evidence. Oxford Bulletin of Economics and Statistics 65 (2): 117-170.

Wößmann, Ludger (2004). Entwicklung betrieblicher Kosten und Nutzen der Berufsausbildung: Einige Anmerkungen zu den Ursachen des Ausbildungsplatzmangels. Ifo Schnelldienst 57 (6): 21-24.

Wößmann, Ludger (2005a). Educational Production in Europe. Economic Policy 20 (43): 445-504.

Wößmann, Ludger (2005b). The Effect Heterogeneity of Central Exams: Evidence from TIMSS, TIMSS-Repeat and PISA. Education Economics 13 (2): 143-169.

Wößmann, Ludger (2005c). Public-Private Partnerships in Schooling: Cross-Country Evidence on their Effectiveness in Providing Cognitive Skills. Program on Education Policy and Governance, Research Paper PEPG 05-09. Cambridge, MA: Harvard University.

Wößmann, Ludger, Paul E. Peterson, eds. (2006). Schools and the Equal Opportunity Problem. Cambridge, MA: MIT Press (forthcoming). 


\section{CESifo Working Paper Series}

(for full list see www.cesifo-group.de)

1716 Chris van Klaveren, Bernard van Praag and Henriette Maassen van den Brink, Empirical Estimation Results of a Collective Household Time Allocation Model, May 2006

1717 Paul De Grauwe and Agnieszka Markiewicz, Learning to Forecast the Exchange Rate: Two Competing Approaches, May 2006

1718 Sijbren Cnossen, Tobacco Taxation in the European Union, May 2006

1719 Marcel Gérard and Fernando Ruiz, Interjurisdictional Competition for Higher Education and Firms, May 2006

1720 Ronald McKinnon and Gunther Schnabl, China's Exchange Rate and International Adjustment in Wages, Prices, and Interest Rates: Japan Déjà Vu?, May 2006

1721 Paolo M. Panteghini, The Capital Structure of Multinational Companies under Tax Competition, May 2006

1722 Johannes Becker, Clemens Fuest and Thomas Hemmelgarn, Corporate Tax Reform and Foreign Direct Investment in Germany - Evidence from Firm-Level Data, May 2006

1723 Christian Kleiber, Martin Sexauer and Klaus Waelde, Bequests, Taxation and the Distribution of Wealth in a General Equilibrium Model, May 2006

1724 Axel Dreher and Jan-Egbert Sturm, Do IMF and World Bank Influence Voting in the UN General Assembly?, May 2006

1725 Swapan K. Bhattacharya and Biswa N. Bhattacharyay, Prospects of Regional Cooperation in Trade, Investment and Finance in Asia: An Empirical Analysis on BIMSTEC Countries and Japan, May 2006

1726 Philippe Choné and Laurent Linnemer, Assessing Horizontal Mergers under Uncertain Efficiency Gains, May 2006

1727 Daniel Houser and Thomas Stratmann, Selling Favors in the Lab: Experiments on Campaign Finance Reform, May 2006

1728 E. Maarten Bosker, Steven Brakman, Harry Garretsen and Marc Schramm, A Century of Shocks: The Evolution of the German City Size Distribution 1925 - 1999, May 2006

1729 Clive Bell and Hans Gersbach, Growth and Enduring Epidemic Diseases, May 2006

1730 W. Bentley MacLeod, Reputations, Relationships and the Enforcement of Incomplete Contracts, May 2006 
1731 Jan K. Brueckner and Ricardo Flores-Fillol, Airline Schedule Competition: ProductQuality Choice in a Duopoly Model, May 2006

1732 Kerstin Bernoth and Guntram B. Wolff, Fool the Markets? Creative Accounting, Fiscal Transparency and Sovereign Risk Premia, May 2006

1733 Emmanuelle Auriol and Pierre M. Picard, Government Outsourcing: Public Contracting with Private Monopoly, May 2006

1734 Guglielmo Maria Caporale and Luis A. Gil-Alana, Modelling Structural Breaks in the US, UK and Japanese Unemployment Rates, May 2006

1735 Emily J. Blanchard, Reevaluating the Role of Trade Agreements: Does Investment Globalization Make the WTO Obsolete?, May 2006

1736 Per Engström and Bertil Holmlund, Tax Evasion and Self-Employment in a High-Tax Country: Evidence from Sweden, May 2006

1737 Erkki Koskela and Mikko Puhakka, Cycles and Indeterminacy in Overlapping Generations Economies with Stone-Geary Preferences, May 2006

1738 Saku Aura and Thomas Davidoff, Supply Constraints and Housing Prices, May 2006

1739 Balázs Égert and Ronald MacDonald, Monetary Transmission Mechanism in Transition Economies: Surveying the Surveyable, June 2006

1740 Ben J. Heijdra and Ward E. Romp, Ageing and Growth in the Small Open Economy, June 2006

1741 Robert Fenge and Volker Meier, Subsidies for Wages and Infrastructure: How to Restrain Undesired Immigration, June 2006

1742 Robert S. Chirinko and Debdulal Mallick, The Elasticity of Derived Demand, Factor Substitution and Product Demand: Corrections to Hicks’ Formula and Marshall's Four Rules, June 2006

1743 Harry P. Bowen, Haris Munandar and Jean-Marie Viaene, Evidence and Implications of Zipf's Law for Integrated Economies, June 2006

1744 Markku Lanne and Helmut Luetkepohl, Identifying Monetary Policy Shocks via Changes in Volatility, June 2006

1745 Timo Trimborn, Karl-Josef Koch and Thomas M. Steger, Multi-Dimensional Transitional Dynamics: A Simple Numberical Procedure, June 2006

1746 Vivek H. Dehejia and Yiagadeesen Samy, Labor Standards and Economic Integration in the European Union: An Empirical Analysis, June 2006

1747 Carlo Altavilla and Paul De Grauwe, Forecasting and Combining Competing Models of Exchange Rate Determination, June 2006 
1748 Olaf Posch and Klaus Waelde, Natural Volatility, Welfare and Taxation, June 2006

1749 Christian Holzner, Volker Meier and Martin Werding, Workfare, Monitoring, and Efficiency Wages, June 2006

1750 Steven Brakman, Harry Garretsen and Charles van Marrewijk, Agglomeration and Aid, June 2006

1751 Robert Fenge and Jakob von Weizsäcker, Mixing Bismarck and Child Pension Systems: An Optimum Taxation Approach, June 2006

1752 Helge Berger and Michael Neugart, Labor Courts, Nomination Bias, and Unemployment in Germany, June 2006

1753 Chris van Klaveren, Bernard van Praag and Henriette Maassen van den Brink, A Collective Household Model of Time Allocation - a Comparison of Native Dutch and Immigrant Households in the Netherlands, June 2006

1754 Marko Koethenbuerger, Ex-Post Redistribution in a Federation: Implications for Corrective Policy, July 2006

1755 Axel Dreher, Jan-Egbert Sturm and Heinrich Ursprung, The Impact of Globalization on the Composition of Government Expenditures: Evidence from Panel Data, July 2006

1756 Richard Schmidtke, Private Provision of a Complementary Public Good, July 2006

1757 J. Atsu Amegashie, Intentions and Social Interactions, July 2006

1758 Alessandro Balestrino, Tax Avoidance, Endogenous Social Norms, and the Comparison Income Effect, July 2006

1759 Øystein Thøgersen, Intergenerational Risk Sharing by Means of Pay-as-you-go Programs - an Investigation of Alternative Mechanisms, July 2006

1760 Pascalis Raimondos-Møller and Alan D. Woodland, Steepest Ascent Tariff Reforms, July 2006

1761 Ronald MacDonald and Cezary Wojcik, Catching-up, Inflation Differentials and Credit Booms in a Heterogeneous Monetary Union: Some Implications for EMU and new EU Member States, July 2006

1762 Robert Dur, Status-Seeking in Criminal Subcultures and the Double Dividend of ZeroTolerance, July 2006

1763 Christa Hainz, Business Groups in Emerging Markets - Financial Control and Sequential Investment, July 2006

1764 Didier Laussel and Raymond Riezman, Fixed Transport Costs and International Trade, July 2006 
1765 Rafael Lalive, How do Extended Benefits Affect Unemployment Duration? A Regression Discontinuity Approach, July 2006

1766 Eric Hillebrand, Gunther Schnabl and Yasemin Ulu, Japanese Foreign Exchange Intervention and the Yen/Dollar Exchange Rate: A Simultaneous Equations Approach Using Realized Volatility, July 2006

1767 Carsten Hefeker, EMU Enlargement, Policy Uncertainty and Economic Reforms, July 2006

1768 Giovanni Facchini and Anna Maria Mayda, Individual Attitudes towards Immigrants: Welfare-State Determinants across Countries, July 2006

1769 Maarten Bosker and Harry Garretsen, Geography Rules Too! Economic Development and the Geography of Institutions, July 2006

1770 M. Hashem Pesaran and Allan Timmermann, Testing Dependence among Serially Correlated Multi-category Variables, July 2006

1771 Juergen von Hagen and Haiping Zhang, Financial Liberalization in a Small Open Economy, August 2006

1772 Alessandro Cigno, Is there a Social Security Tax Wedge?, August 2006

1773 Peter Egger, Simon Loretz, Michael Pfaffermayr and Hannes Winner, Corporate Taxation and Multinational Activity, August 2006

1774 Jeremy S.S. Edwards, Wolfgang Eggert and Alfons J. Weichenrieder, The Measurement of Firm Ownership and its Effect on Managerial Pay, August 2006

1775 Scott Alan Carson and Thomas N. Maloney, Living Standards in Black and White: Evidence from the Heights of Ohio Prison Inmates, 1829 - 1913, August 2006

1776 Richard Schmidtke, Two-Sided Markets with Pecuniary and Participation Externalities, August 2006

1777 Ben J. Heijdra and Jenny E. Ligthart, The Transitional Dynamics of Fiscal Policy in Small Open Economies, August 2006

1778 Jay Pil Choi, How Reasonable is the 'Reasonable' Royalty Rate? Damage Rules and Probabilistic Intellectual Property Rights, August 2006

1779 Ludger Woessmann, Efficiency and Equity of European Education and Training Policies, August 2006 